In cooperation with U.S. Army Corps of Engineers

\title{
Monitoring of Stage and Velocity, for Computation of Discharge in the Summit Conduit near Summit, Illinois, 2010-2012
}

Open-File Report 2012-1244 



\section{Monitoring of Stage and Velocity, for Computation of Discharge in the Summit Conduit near Summit, Illinois, 2010-2012}

By Kevin K. Johnson and Greg E. Goodwin

In cooperation with U.S. Army Corps of Engineers

Open-File Report 2012-1244 


\title{
U.S. Department of the Interior SALLY JEWELL, Secretary
}

\section{U.S. Geological Survey Suzette M. Kimball, Acting Director}

\author{
U.S. Geological Survey, Reston, Virginia: 2013
}

For more information on the USGS - the Federal source for science about the Earth, its natural and living resources, natural hazards, and the environment, visit http://www.usgs.gov or call 1-888-ASK-USGS.

For an overview of USGS information products, including maps, imagery, and publications, visit http://www.usgs.gov/pubprod

To order this and other USGS information products, visit http://store.usgs.gov

Any use of trade, firm, or product names is for descriptive purposes only and does not imply endorsement by the U.S. Government.

Although this information product, for the most part, is in the public domain, it also may contain copyrighted materials as noted in the text. Permission to reproduce copyrighted items must be secured from the copyright owner.

Suggested citation:

Johnson, K.K. and Goodwin, G.E., 2013, Monitoring of stage and velocity for computation of discharge in the Summit Conduit near Summit, Illinois, 2010-2012: U.S. Geological Survey Open-File Report 2012-1244, 45 p. 


\section{Contents}

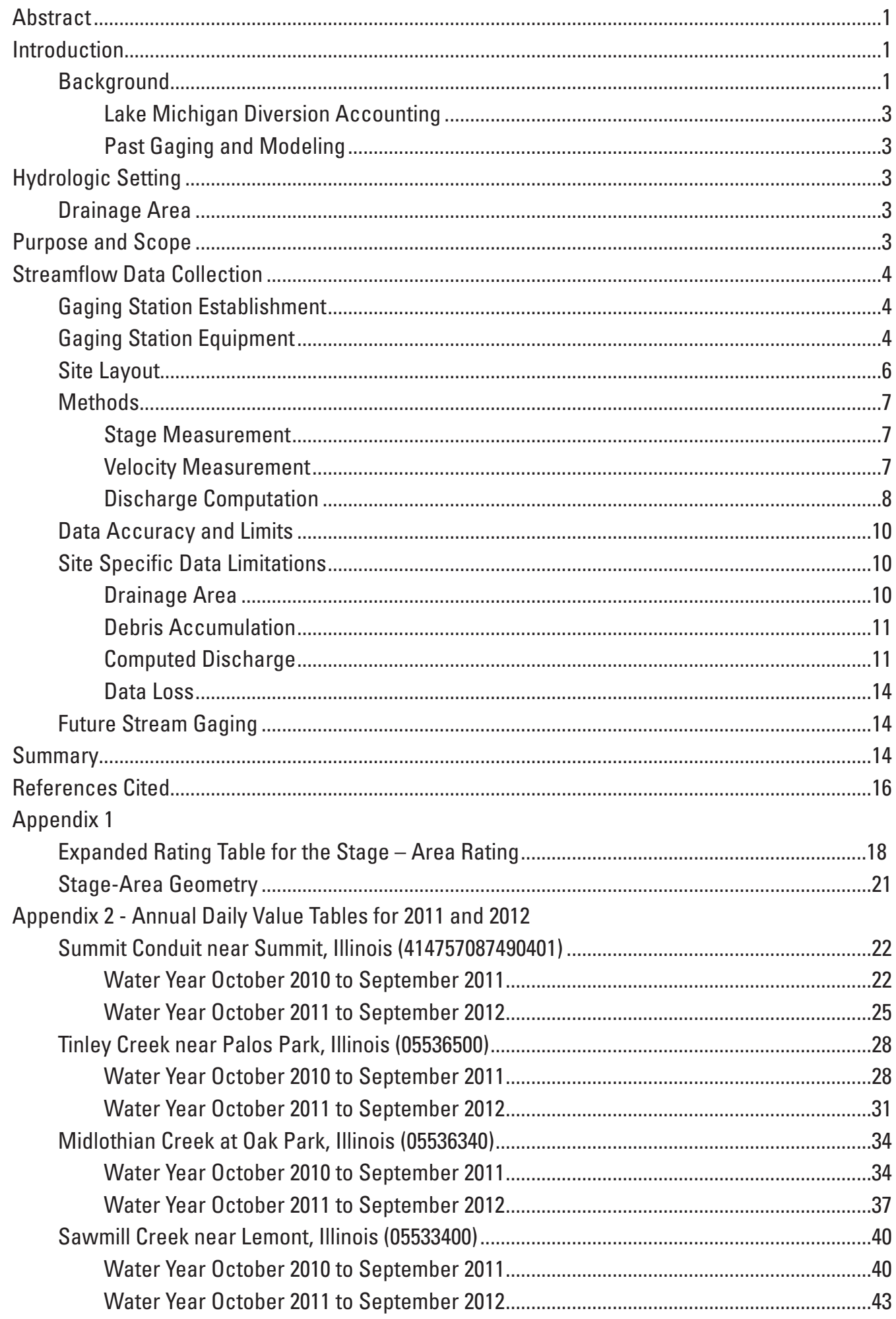




\section{Figures}

1. Map of the location and orientation of the Summit Conduit

2. Map showing the drainage area and tributaries of the Summit Conduit near Summit, Illinois

3. Photographs of the Summit Conduit near Summit, Illinois stream gage before and after October 10, 2012, showing the gage features. .5

4. View of the stream gaging station at the Summit Conduit at Summit, Illinois. Locations of significant features, reference marks and gage equipment are indicated in the diagram 6

5. Illustration of dynamic boundary adjustment of velocity profile from the SonTek Argonaut SW acoustic Doppler velocity meter (Levesque and Oberg, 2012)

6. The velocity-velocity plot of the mean index-velocity (in feet per second) measured by an acoustic Doppler velocity meter (ADVM) as compared to the mean channel velocity (in feet per second) as measured discharge divided by the rated area for the gaging station at the Summit Conduit at Summit, Illinois

7. Diagram indicating the cross-sectional area geometry with dimensions for calculating the rated area in the area of the measured acoustic Doppler velocity meter (ADVM) velocity

8. The stage-area rating curve developed from equations 3 and 4 from the channel geometry in figure 7

9. Plot of acoustic Doppler velocity meter (ADVM) data illustrating a period when debris covered the meter, January 27 to March 17, 2011

10. Hydrograph of water years 2011 and 2012 showing Summit Conduit at Summit, Sawmill Creek near Lemont, Midlothian Creek near Oak Park, and Tinley Creek near Palos Hills

11. Data lost during five medium to high flow events between June 9 and June 24, 2011

\section{Tables}

1. Mean annual discharge for water years 2011 and 2012 for Summit Conduit stream gaging station and three comparison stream gaging stations 


\section{Conversion Factors}

\begin{tabular}{lcl}
\multicolumn{1}{c}{ Inch/Pound to SI } & & \\
\hline \multicolumn{1}{c}{ Multiply } & By & To obtain \\
\hline inch (in.) & Length & \\
inch (in.) & 2.54 & centimeter $(\mathrm{cm})$ \\
foot (ft) & 25.4 & millimeter $(\mathrm{mm})$ \\
mile (mi) & 0.3048 & meter $(\mathrm{m})$ \\
& 1.609 & kilometer $(\mathrm{km})$ \\
\hline square foot (ft2) & Area & \\
square foot (ft2) & 929.0 & square centimeter $(\mathrm{cm} 2)$ \\
\hline & 0.09290 & square meter $(\mathrm{m} 2)$ \\
\hline cubic foot per second (ft3/s) & Flow rate & \\
\hline
\end{tabular}

Temperature in degrees Celsius $\left({ }^{\circ} \mathrm{C}\right)$ may be converted to degrees Fahrenheit $\left({ }^{\circ} \mathrm{F}\right)$ as follows:

${ }^{\circ} \mathrm{F}=\left(1.8 \mathrm{x}^{\circ} \mathrm{C}\right)+32$

Temperature in degrees Fahrenheit $\left({ }^{\circ} \mathrm{F}\right)$ may be converted to degrees Celsius $\left({ }^{\circ} \mathrm{C}\right)$ as follows:

${ }^{\circ} \mathrm{C}=\left({ }^{\circ} \mathrm{F}-32\right) / 1.8$

Vertical coordinate information is referenced to the insert datum name (and abbreviation) here for instance, "North American Vertical Datum of 1988 (NAVD 88)."

Horizontal coordinate information is referenced to the insert datum name (and abbreviation) here for instance, "North American Datum of 1983 (NAD 83)."

Altitude, as used in this report, refers to distance above the vertical datum.

Water year, defined as the 12-month period October 1, for any given year through September 30 , of the following year. The water year is designated by the calendar year in which it ends and which includes 9 of the 12 months. Thus, the year ending September 30, 2011 is called the "2011" water year 


\section{Abbreviations}

$\begin{array}{ll}\text { ADVM } & \text { acoustic Doppler velocity meter } \\ \text { BOR } & \text { Bureau of Reclamation } \\ \text { CSG } & \text { Crest-stage gage } \\ \text { CSSC } & \text { Chicago Sanitary and Ship Canal } \\ \text { dB } & \text { Decibels } \\ \text { DCP } & \text { Data collection platform } \\ \text { DOI } & \text { Department of the Interior } \\ \text { GOES } & \text { Geostationary operational environmental satellite } \\ \text { LMDA } & \text { Lake Michigan diversion accounting } \\ \text { MSD } & \text { Metropolitan Sanitary District } \\ \text { MWRD } & \text { Metropolitan Water Reclamation District } \\ \text { NPDES } & \text { National Pollutant Discharge Elimination System } \\ \text { RP } & \text { reference point } \\ \text { SNR } & \text { Signal to noise ratio } \\ \text { USACE } & \text { U.S. Army Corps of Engineers } \\ \text { USGS } & \text { U.S. Geological Survey } \\ \text { WY } & \text { water year }\end{array}$




\title{
Monitoring of Stage and Velocity, for Computation of Discharge in the Summit Conduit near Summit, Illinois 2010-2012
}

\author{
By Kevin K. Johnson and Greg E. Goodwin
}

\section{Abstract}

Lake Michigan diversion accounting is the process used by the U. S. Army Corps of Engineers to quantify the amount of water that is diverted from the Lake Michigan watershed into the Illinois and Mississippi River Basins. A network of streamgages within the Chicago area waterway system monitor tributary river flows and the major river flow on the Chicago Sanitary and Ship Canal near Lemont as one of the instrumental tools used for Lake Michigan diversion accounting. The mean annual discharges recorded by these streamgages are used as additions or deductions to the mean annual discharge recorded by the main stream gaging station currently used in the Lake Michigan diversion accounting process, which is the Chicago Sanitary and Ship Canal near Lemont, Illinois (station number 05536890).

A new stream gaging station, Summit Conduit near Summit, Illinois (station number 414757087490401), was installed on September 23, 2010, for the purpose of monitoring stage, velocity, and discharge through the Summit Conduit for the U.S. Army Corps of Engineers in accordance with Lake Michigan diversion accounting. Summit Conduit conveys flow from a small part of the lower Des Plaines River watershed underneath the Des Plaines River directly into the Chicago Sanitary and Ship Canal. Because the Summit Conduit discharges into the Chicago Sanitary and Ship Canal upstream from the stream gaging station at Lemont, Illinois, but does not contain flow diverted from the Lake Michigan watershed, it is considered a flow deduction to the discharge measured by the Lemont stream gaging station in the Lake Michigan diversion accounting process. This report offers a technical summary of the techniques and methods used for the collection and computation of the stage, velocity, and discharge data at the Summit Conduit near Summit, Illinois stream gaging station for the 2011 and 2012 Water Years.

The stream gaging station Summit Conduit near Summit, Illinois (station number 414757087490401) is an example of a nonstandard stream gage. Traditional methods of equating stage to discharge historically were not effective. Examples of the nonstandard conditions include the converging tributary flows directly upstream of the gage; the trash rack and walkway near the opening of the conduit introducing turbulence and occasionally entraining air bubbles into the flow; debris within the conduit creating conditions of variable backwater and the constant influx of smaller debris that escapes the trash rack and catches or settles in the conduit and on the equipment. An acoustic Doppler velocity meter was installed to measure stage and velocity to compute discharge. The stage is used to calculate area based the stage-area rating. The index-velocity from the acoustic Doppler velocity meter is applied to the velocityvelocity rating and the product of the two rated values is a rated discharge by the index-velocity method. Nonstandard site conditions prevalent at the Summit Conduit stream gaging station generally are overcome through the index-velocity method. Despite the difficulties in gaging and measurements, improvements continue to be made in data collection, transmission, and measurements. Efforts to improve the site and to improve the ratings continue to improve the quality and quantity of the data available for Lake Michigan diversion accounting.

\section{Introduction}

\section{Background}

Summit Conduit, built in 1918, is a 6 feet (ft) wide by $7 \mathrm{ft}$ high irregular concrete conduit that extends approximately $1 / 3$ of a mile underneath the Des Plaines River near Summit, Illinois (fig. 1). A series of ditches, leading to the Summit Conduit, drain approximately 5.4 square miles $\left(\mathrm{mi}^{2}\right)$ of the lower Des Plaines River floodplain and discharges the flow directly into the Chicago Sanitary and Ship Canal (CSSC). The drainage ditches and the conduit were originally constructed to drain the farmland behind the McCook Levee on the right bank of the Des Plaines River. The farmland has been replaced by a rock quarry, industrial facilities, and semipermeable parking lots. The ditches still function as a drainage for industry and parking as well as a receptor for a couple of National Pollutant Discharge Elimination System (NPDES) permits for elimination of stormwater discharges from construction site activities. Summit Conduit is located near Summit, Ill and enters the CSSC at U.S. Geological Survey (USGS) river mile 313.3, 22.2 miles upstream from the Lockport powerhouse (fig. 1, Kollias, 2008). 


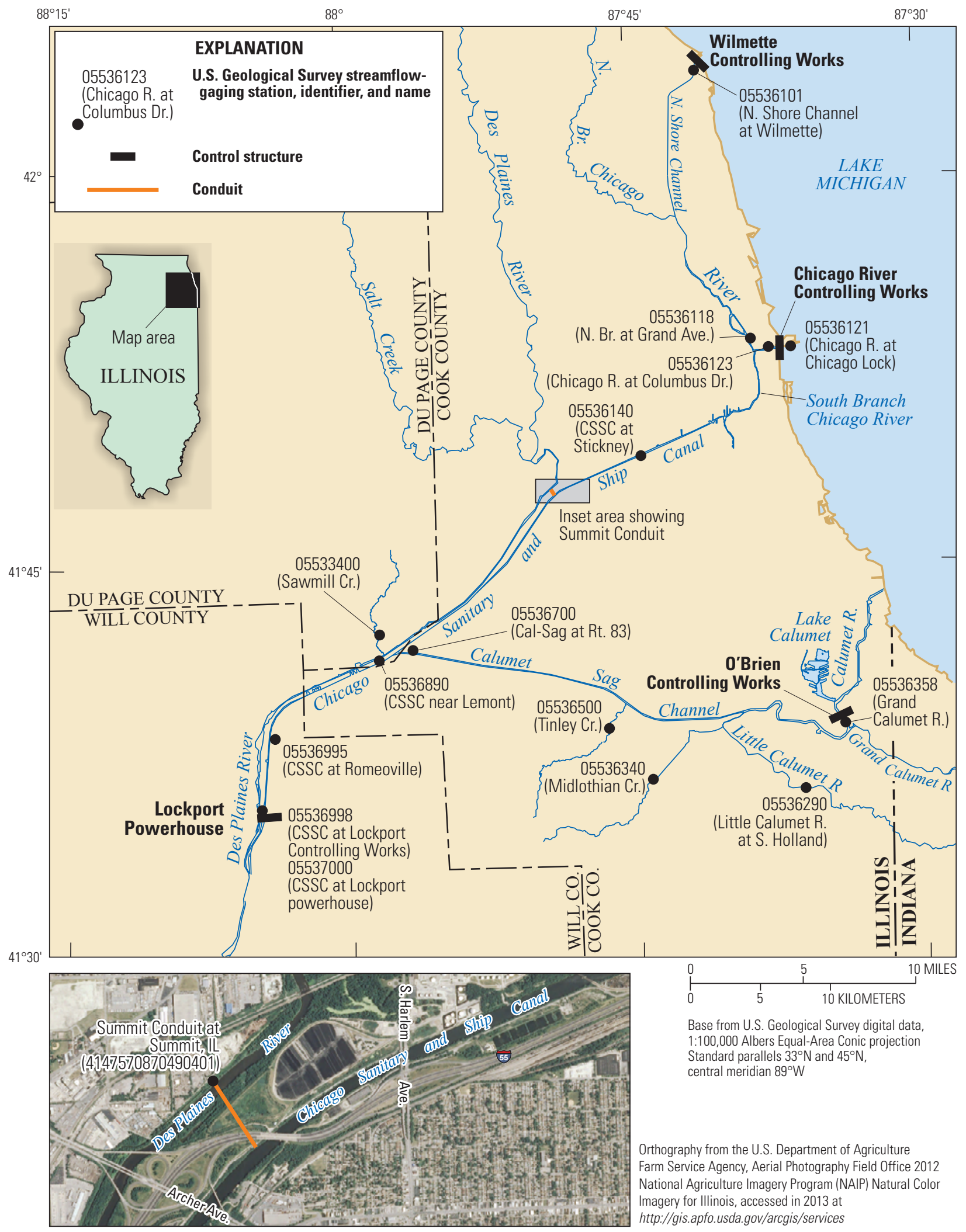

Figure 1. Map of the location and orientation of the Summit Conduit. 


\section{Lake Michigan Diversion Accounting}

A U.S. Supreme Court ruling limits the amount of water that the State of Illinois is allowed to divert from Lake Michigan into the Illinois and Mississippi River Basins (Johnson and others, 2012). The U.S. Army Corps of Engineers (USACE) is tasked with accounting for the flows diverted from Lake Michigan. Lake Michigan diversion accounting (LMDA) is the process used by the USACE to quantify the amount of water diverted from Lake Michigan watershed by the State of Illinois. The LMDA depends on data collection from a network of streamgages and rain gages that monitor diverted flows as well as statistical models used to estimate diverted flows where gaging is not feasible. The resulting data is used by the USACE to calculate a series of additions and deductions to determine a final diversion discharge. Discharge data values recorded by USGS stream gaging station numbers 05536995 (Chicago Sanitary and Ship Canal at Romeoville, Illinois; 1984 to 2005) and 05536890 (Chicago Sanitary and Ship Canal near Lemont, Illinois; 2006 to present), are the primary stream gaging stations that measure diverted flows used in the LMDA process (Espey and others, 1981, 1987, 1994, 2001, 2004, 2009, Jackson and others, 2011, Johnson and others, 2012).

The location where the Summit Conduit discharges into the CSSC is upstream from the gaging station near Lemont, Illinois. Since the Summit Conduit conveys stormwater from outside of the Lake Michigan drainage basin and discharges upstream from the gaging station near Lemont, Illinois; a deduction, in the quantity of the Summit Conduit discharge, is applied to the Lemont stream gaging station discharge values in accordance with LMDA.

\section{Past Gaging and Modeling}

Previous attempts to monitor the discharge through the Summit Conduit have not yielded accurate results (Espey and others, 1981). The Metropolitan Sanitary District of Greater Chicago (MSD), now the Metropolitan Water Reclamation District of Greater Chicago (MWRD), operated a stream gaging station at the conduit for a period from the early 1960s into the 1980s. However, because of difficult monitoring conditions, the methods used during this time period were not satisfactory and data from this period contained substantial errors as noted by the First Technical Review Committee for LMDA (Espey and others, 1981). Since that time, the USACE has used a modeling approach to estimate discharge through the Summit Conduit. The USACE modeling approach used a rainfall-runoff model to simulate discharges through the conduit; however, the unsteady nature of the watershed and lack of validation data collection has led to uncertainty in modeled discharges.

\section{Hydrologic Setting}

\section{Drainage Area}

The watershed tributary to the Summit Conduit is located in southeastern Cook County and encompasses parts of the villages of Countryside, Hodgkins, McCook, La Grange and Lyons. As reported in the Detailed Watershed Plan for the Lower Des Plaines River Watershed: Volume 1 (Burke, 2011), the watershed area can be described as being:

"roughly bounded by Willow Springs Road to the west, Joliet Road to the south and east, and 47 th

Street to the north. The northeast portion of the drainage area extends southeast past Joliet Road to the McCook Levee to the northeast and the Des Plaines River south of the McCook Levee to approximately East 55th Street".

Summit Conduit also conveys the flows from the McCook Ditch, the East Avenue Ditch subwatershed with the Plainfield Road storm sewer. The drainage area of the watershed that drains into the Summit Conduit is approximately $5.4 \mathrm{mi}^{2}$ and can be seen in figure 2. The two main tributaries in addition to receiving surface runoff, also receive additional storm sewer flow and intermittent point discharges from the watershed. The McCook Ditch and the East Avenue Ditch with the Plainfield Road storm sewer are highlighted in figure 2. The area within the watershed generally can be described as flat to gently sloping. Land use for the area is primarily residential and commercial/industrial.

\section{Purpose and Scope}

The purpose of this report is to provide a technical description of the monitoring of stage, velocity, and discharge through the Summit Conduit near Summit, Illinois. The Summit Conduit near Summit, Illinois stream gaging station (station number 414757087490401 ) was installed by the USGS to accurately quantify the amount of discharge conveyed by the Summit Conduit into the CSSC in accordance with LMDA. The discharge data computed for this site may be used for validation and calibration of the rainfall runoff model and will be beneficial to improving the accuracy of another variable in LMDA. 


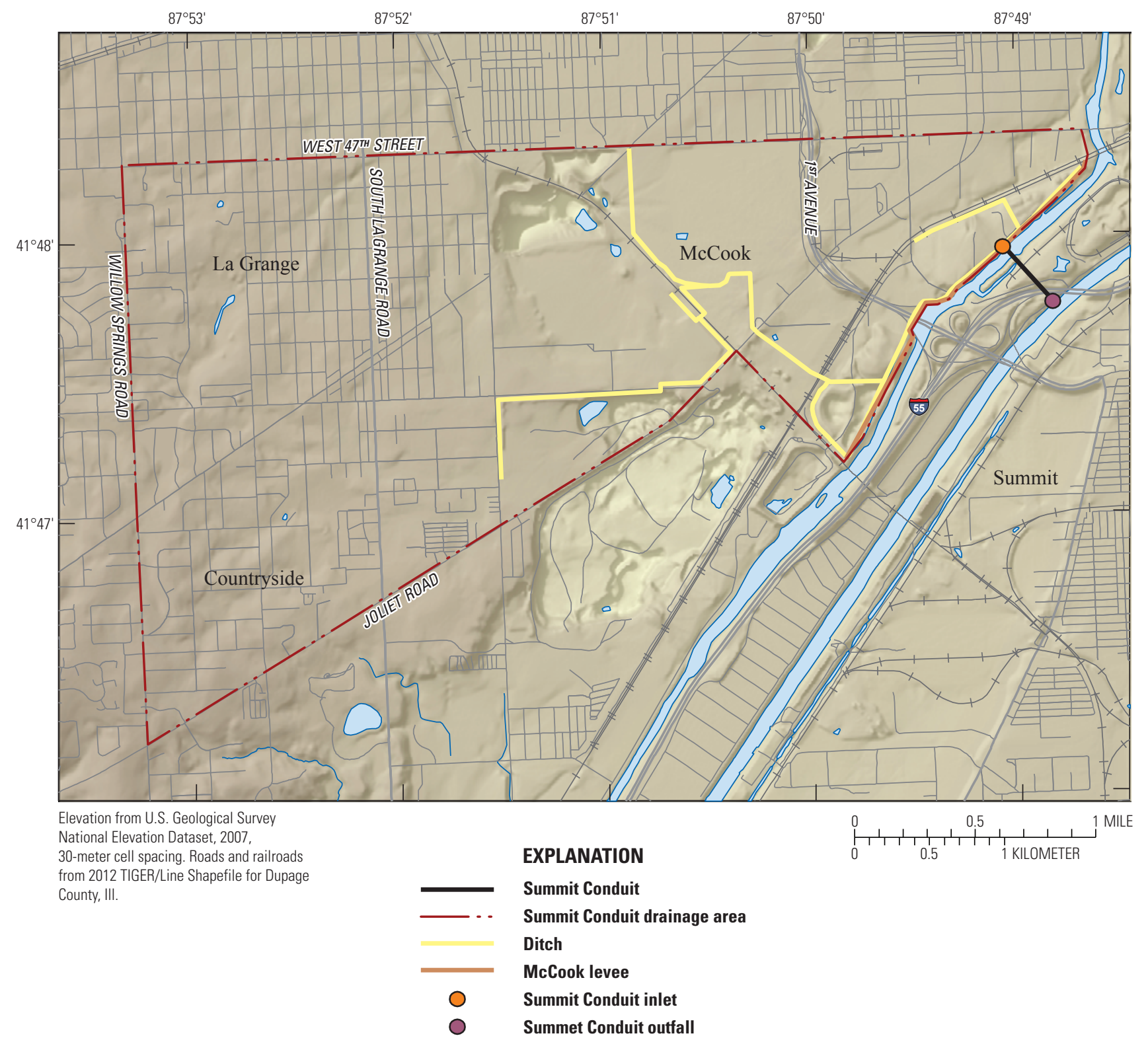

Figure 2. Map showing the drainage area and tributaries of the Summit Conduit near Summit, Illinois.

\section{Streamflow Data Collection}

\section{Gaging Station Establishment}

The stream gaging station was established by USGS personnel on September 23, 2010, and the official start of data collection was October 1,2010. The stream gaging station consists of a reference gage, an acoustic Doppler velocity meter (ADVM) that continuously records stage and velocity, and a crest-stage gage (CSG) to validate high flow stage recordings. Recorded stage and velocity readings are applied to ratings to calculate discharge.

\section{Gaging Station Equipment}

The primary stage and velocity recorder at the gaging station is a SonTek Argonaut-SW ADVM, which consists of three "upward-looking" transducers for measuring water level and water velocity. The ADVM is bolted to the bottom of the Summit Conduit, and is located $20 \mathrm{ft}$ inside the upstream opening. Water level is measured as a result of the reflection of the acoustic signal off of the water surface. The water velocity also is measured using the Doppler shift principle with acoustic signals reflected off of particulates moving within the water flow. For a more detailed description of the principles 
involved in ADVM technology refer to Simpson (2001) and Levesque and Oberg (2012). The recorder enclosure is a 6 inch (in.) x 8 in. x 18 in. steel box containing a voltage regulator and battery, which supply power to the ADVM. Power to the battery is supplemented by a solar panel. The reference gage is a reference point (RP-1) of known elevation from which "tape-down" measurements can be made to the water surface. RP-1 is a narrow aluminum plate bolted to the top of the Summit Conduit opening, with two file marks, located $2 \mathrm{ft}$ to the right (if looking downstream) of the gage enclosure. A CSG, for verifying event peaks, also is installed at the gaging station and is located $3.5 \mathrm{ft}$ to the right of RP-1 (if looking downstream). The CSG consists of a $10 \mathrm{ft}$ long by 1 in. thick by $1.5 \mathrm{in}$. wide board enclosed in a 2 in. galvanized steel pipe bolted to the conduit abutment by two steel brackets. A second reference point for obtaining the water-surface elevation (RPC) consists of two file marks located on the upper bracket of the CSG.
The original gage configuration was flooded a few times causing a short circuit in the battery and resulted in a loss of data. The lack of telemetry also resulted in loss of data because the ADVM would become covered with debris and there was no way of knowing until the next site visit and instrument inspection. To remedy this, on October 10, 2012, the gage equipment was upgraded to a Design Analysis WaterLog 522+ data collection platform (DCP) with a geostationary operational environmental satellite (GOES) radio transmitter, and the steel box was replaced with a new 24 in. x 24 in. x 10 in. environmental enclosure on a 4-foot high pedestal. The height of the pedestal is greater than the highest stage recorded in the 2 years of record. The DCP was installed to improve the quality and quantity of data collected. Real-time data can be monitored daily to ensure the ADVM is not covered with debris. The gage layout as it was originally installed, and from Oct 12, 2012, after the gage upgrade is shown in figure 3.

\section{A}

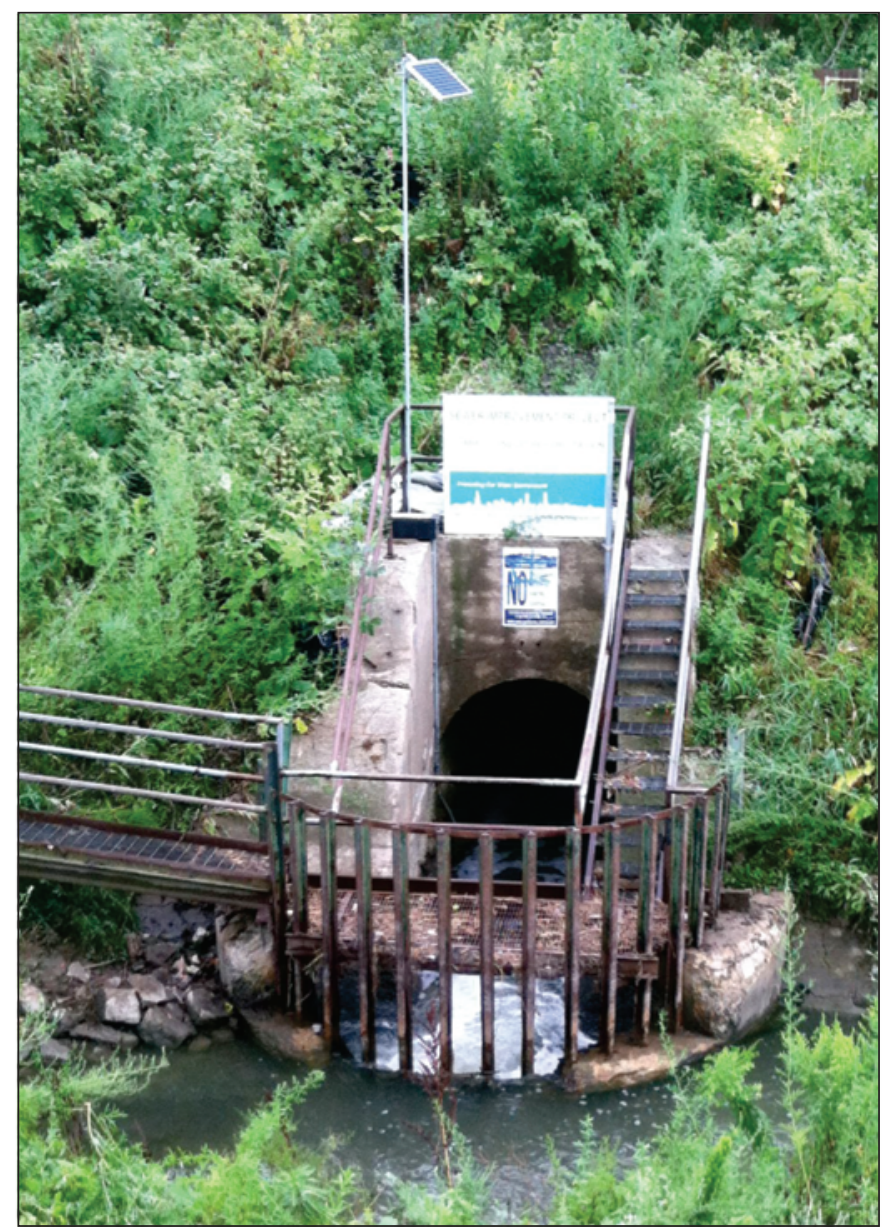

$B$

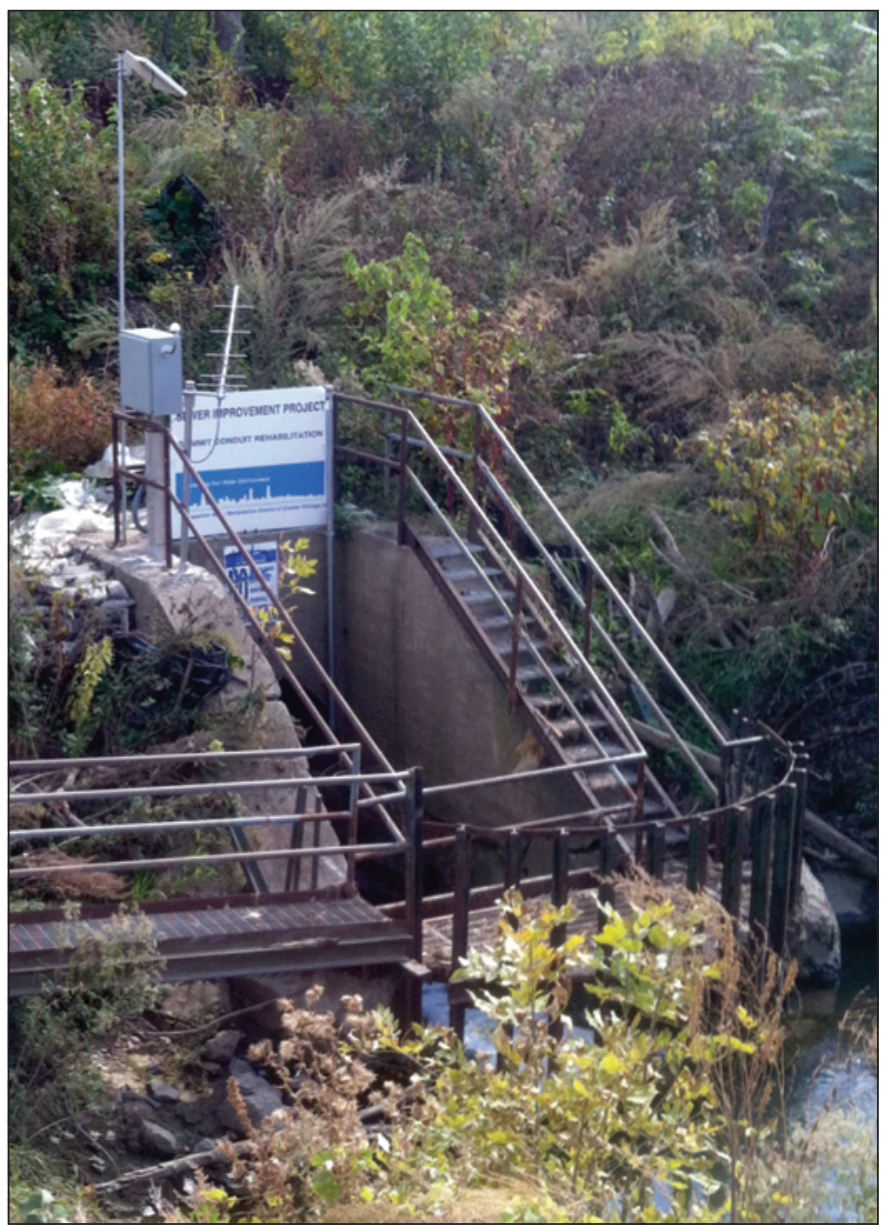

Figure 3. Photographs of the Summit Conduit near Summit, Illinois stream gage before and after October 10, 2012, showing the gage features. 


\section{Site Layout}

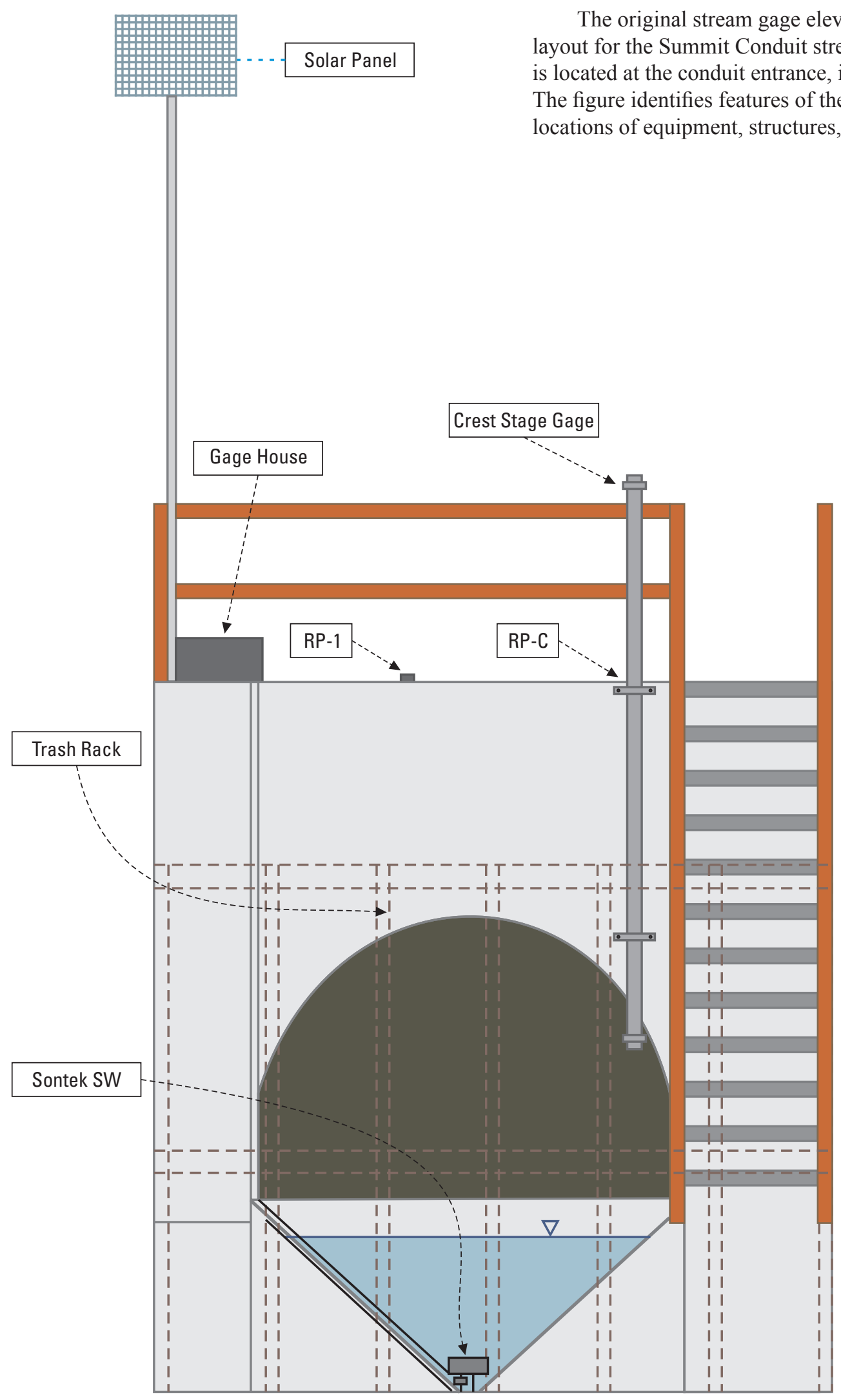

Figure 4. View of the stream gaging station at the Summit Conduit at Summit, Illinois. Locations of significant features, reference marks and gage equipment are indicated in the diagram. 


\section{Methods}

\section{Stage Measurement}

The primary stage record for the Summit Conduit steam gaging station is recorded by the ADVM. The ADVM uses a vertical acoustic beam to measure the water-surface elevation. The vertical beam can measure depths ranging from 0.6 to $16 \mathrm{ft}$ of water over the sensor to an accuracy of $\pm 0.01 \mathrm{ft}$ as reported by SonTek/YSI (SonTek/YSI, 2006). Stage for this gaging station is recorded on a 10-minute interval and is stored internally by the ADVM and DCP; the data is also transmitted by GOES radio through the DCP once every hour. During periodic discharge measurements described in the next section, the stage data is collected at a one minute interval.

Manual stage measurements are made on a periodic basis by USGS personnel for comparison to recorded values. These stage measurements are made from reference points (RP-1 or RP-C) and collected according to USGS Techniques and Methods, book 3, chap. A7, "Stage Measurement at Gaging Stations" (Sauer and Turnipseed, 2010). Manual stage measurements also are applied to a stage-area rating that is part of the index-velocity ratings for this station and are an important part of calculating the mean channel velocity from the measured discharge. For a more detailed description of index-velocity ratings, refer to Levesque and Oberg (2012).

\section{Velocity Measurement}

Velocity measurements at the Summit Conduit stream gaging station are also recorded by the ADVM. The ADVM uses two beams (one facing upstream and one facing downstream), fixed at a $45^{\circ}$ angle that measure velocity using the acoustic Doppler method (SonTek/YSI, 2006). The two beams use dynamic boundary adjustment based on the water level to output a vertically averaged velocity for the depth of the water column. There is a gap above the ADVM for blanking the acoustic signal and dampen the ringing of the transducers and another gap near the water surface where the beam impinges on the ceiling or the air-water interface (fig. 5). Velocities are collected on a 10-minute interval (and samples are averaged for 2 minutes). The velocity data is stored internally by the ADVM and DCP and is transmitted by GOES Satellite radio through the DCP once every hour. Manual velocity measurements are collected periodically by USGS personnel to validate the accuracy of the ADVM data. The velocity measurements are collected at the opening of the conduit, 25 feet upstream from the ADVM and are recorded with a handheld acoustic Doppler velocimeter (ADV) according to USGS Techniques and Methods, book 3, chap. A8, "Discharge Measurements at Gaging Stations" (Turnipseed and Sauer, 2010). When the measurements are made at the opening of the conduit the hydrographer generally is able to stand with one foot on each wall of the culvert to minimize any flow disturbance that would affect the velocity comparison. During the periodic discharge measurements that are made for creating and maintaining the velocity-velocity rating, the sampling interval and averaging intervals of the ADVM are changed to average and record every 60 seconds to obtain a more detailed record of stage and velocity during the manual measurement period. The data collection is completed according to the guidance found in Levesque and Oberg (2012). When the measurement is finished the recorder is set back to the 2-minute averaging interval and 10-minute sampling intervals.

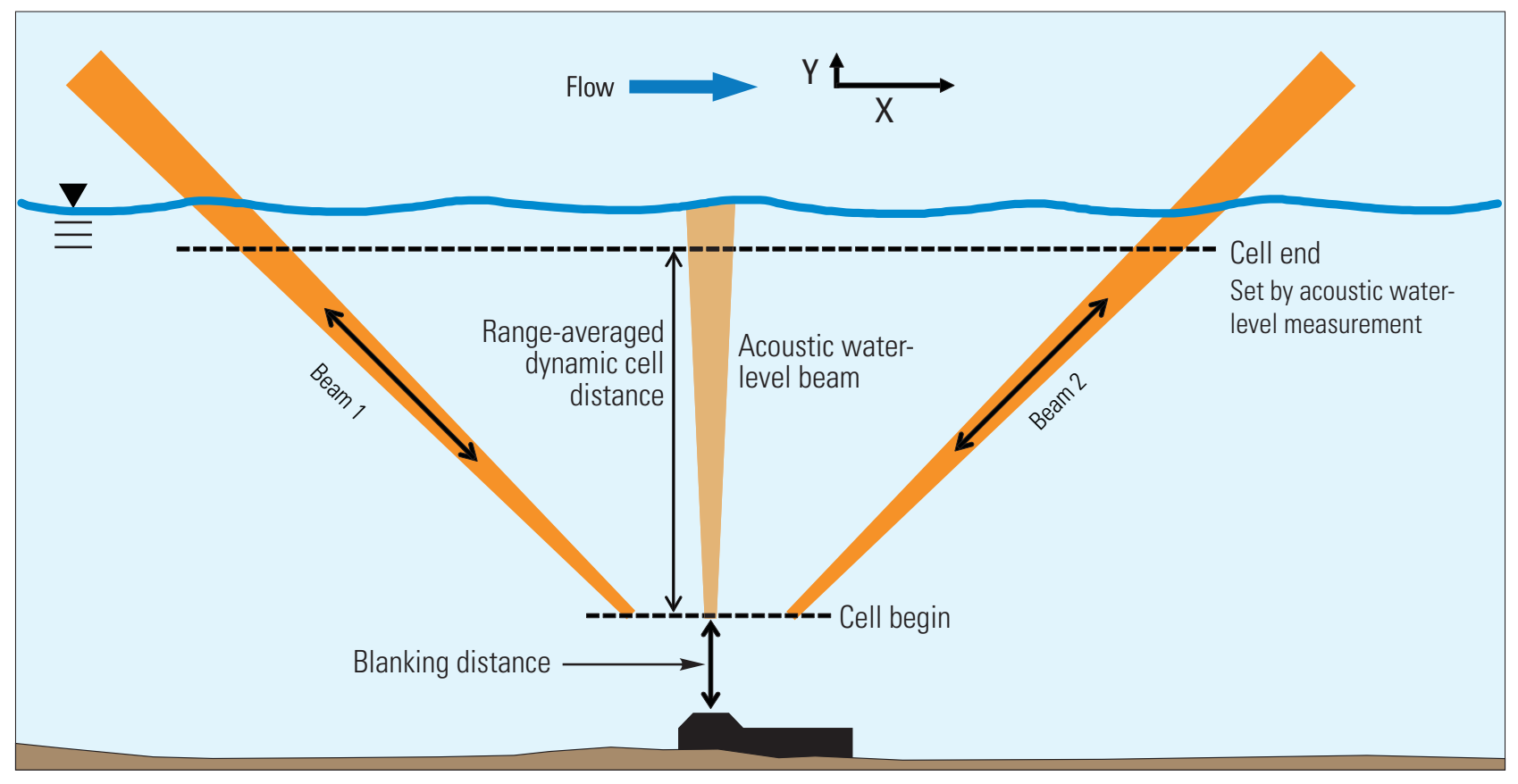

Figure 5. Illustration of dynamic boundary adjustment of velocity profile from the SonTek Argonaut SW acoustic Doppler velocity meter (Levesque and Oberg, 2012). 


\section{Discharge Computation}

Discharge at the Summit Conduit stream gaging station is computed using the Index-Velocity method which combines a velocity-velocity rating and a stage-area rating developed according to USGS Water-Supply Paper 2175, vol. 2 (Rantz and others, 1982) and Computing Discharge Using the Index Velocity Method-Techniques and Methods, book 3, chap. A23 (Levesque and Oberg, 2012). The method is explained by the following equation:

$$
Q_{r}=V_{r} \times A_{r}
$$

where,

$$
\begin{array}{ll}
Q_{r} & \text { is computed discharge } \\
V_{r} & \text { is the average velocity in the cross-section } \\
A_{r} & \text { from the velocity-velocity rating } \\
& \text { is cross-sectional area of the channel from the } \\
\text { stage-area rating }
\end{array}
$$

The index-velocity method uses the velocities collected by the ADVM as an index to the mean-channel velocities collected manually during discharge measurements. Mean-channel velocities are calculated from measured discharges divided by the rated flow area calculated from the time-weighted mean gage height during the measurement period. The rated flow area is the area of the channel determined geometrically from the channel dimensions and the resulting rating equations or table. Using linear regression, the ADVM velocities are then related to the mean-channel velocities to create the velocityvelocity rating (fig. 6). Twenty-seven discharge measurements were used to develop velocity-velocity rating 1.0. The range of measured discharges for the Summit Conduit was from 0.56 to 13.1 cubuc feet per second $\left(\mathrm{ft}^{3} / \mathrm{s}\right)$ and stage ranging from 0.74 to $2.36 \mathrm{ft}$. The velocity used in creating the rating is the result of dividing the measured discharge by the rated area. The range of velocities used in developing the rating was 0.25 to $1.93 \mathrm{ft}^{3} / \mathrm{s}$. Equation 2 was obtained from a regression analysis of the velocity data from the 27 measurements.

$$
V_{r}=0.8859 \times V_{i}+0.1255
$$

where,

$$
\begin{gathered}
V_{r} \quad \begin{array}{c}
\text { is the average velocity in the cross-section } \\
\text { from the velocity-velocity rating, and }
\end{array} \\
V_{i} \quad \begin{array}{c}
\text { is the index velocity from the time averaged } \\
\text { velocity from the ADVM. }
\end{array}
\end{gathered}
$$

The cross-section where ADVM velocities are measured is diagrammed in figure 7. Area is dependent on the stage in the cross-section and can be computed using a stage-area rating. The stage area rating for the gaging station at Summit Conduit is represented by equations 3 through 5 , which are represented by the plot in figure 8. Equations 3, 4, and 5 are based on the geometry of a trapezoid and a circle with adjustment for the overlap of the two shapes. A detailed discussion of this geometric site configuration can be found in Chow (1959), Lindburg (1992), and the U.S. Department of Interior (DOI) Bureau of Reclamation (BOR) Water Resources Research Laboratory: Water Measurement Manual (2001). An expanded rating table for the results of equations 3 through 5 and the rating curve in figure 8 is provided in appendix 1.

From $0 \leq h<2.5$

$$
A=\left(b+z y_{1}\right) y_{1}
$$

From $2.5 \leq h<4$

$$
\begin{gathered}
A=K-K_{t p} \\
d=h
\end{gathered}
$$

From $4 \leq h \leq 7$

$$
\begin{gathered}
A=\pi r^{2}-K-K_{t p} \\
d=2 r-h
\end{gathered}
$$

where

$$
\begin{gathered}
K=\frac{r^{2}(\theta-\sin \theta)}{2} \\
\theta=2 \cos ^{-1}\left(\frac{r-d}{r}\right)
\end{gathered}
$$

where,

$$
\begin{array}{cl}
A & \text { is cross-sectional area }\left(\mathrm{ft}^{2}\right) \\
h & \text { is water-surface elevation }(\mathrm{ft}) \\
r & \text { is the radius of the pipe part of the section } \\
d & \text { is the part of depth contained in the circle } \\
& \text { with radius r } \\
K & \text { is the circular segment area } \\
K_{t p} & \text { is the circular segment area which is entirely } \\
& \text { contained within the trapezoidal part of the } \\
\theta & \text { is the central angle of the circle }
\end{array}
$$

The computed discharge is simply the product of the rated average cross-sectional velocity and the cross-sectional area of the channel (equation 1). 


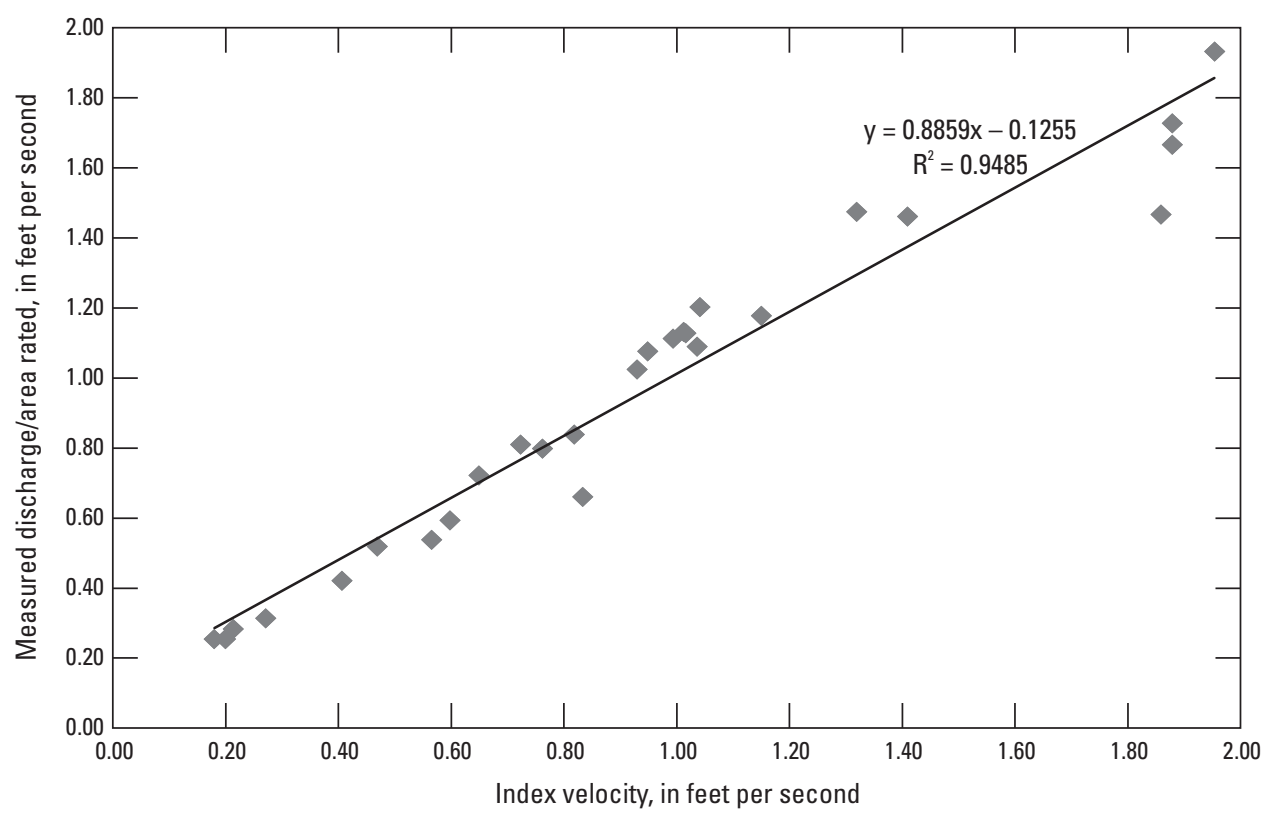

Figure 6. The velocity-velocity plot of the mean index-velocity (in feet per second) measured by an acoustic Doppler velocity meter (ADVM) as compared to the mean channel velocity (in feet per second) as measured discharge divided by the rated area for the gaging station at the Summit Conduit at Summit, Illinois.

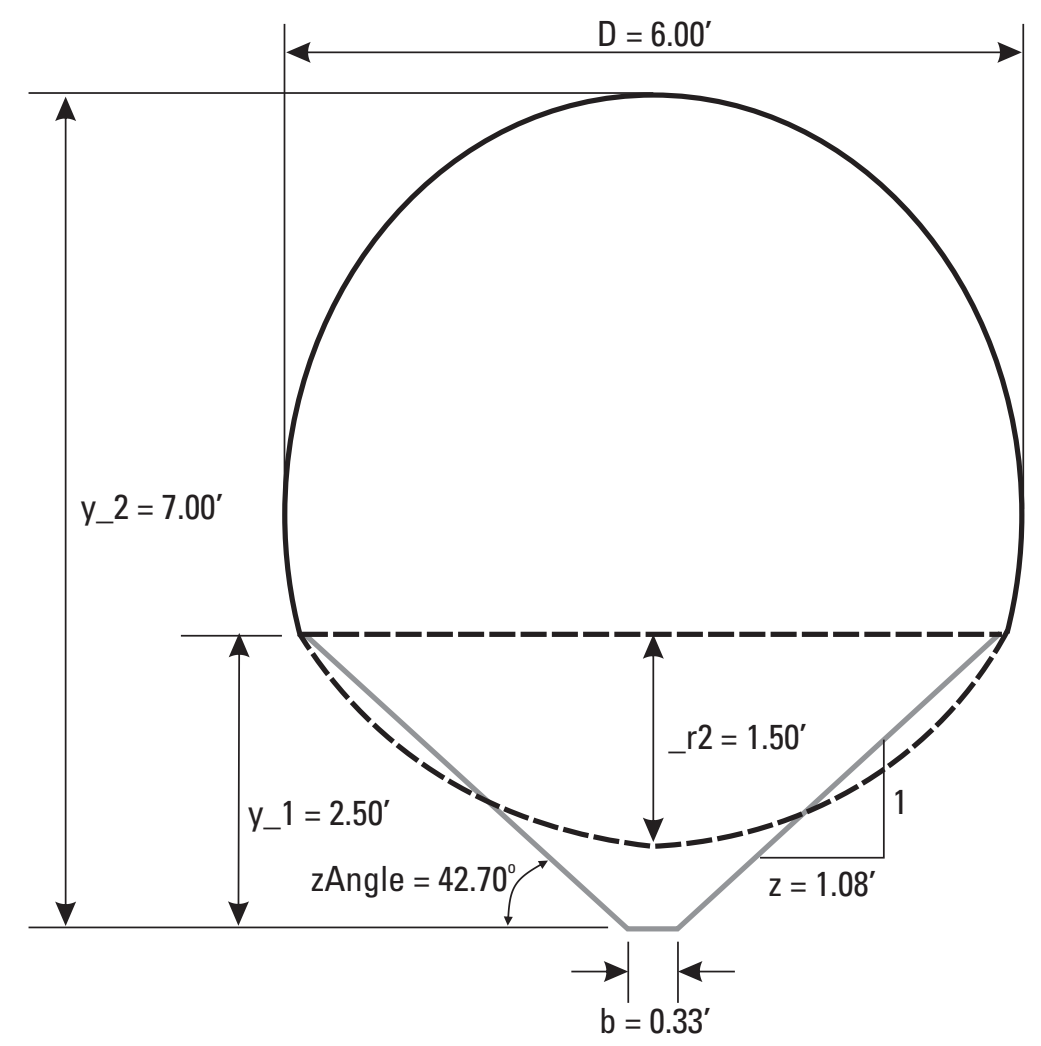

Figure 7. Diagram indicating the cross-sectional area geometry with dimensions for calculating the rated area in the area of the measured acoustic Doppler velocity meter (ADVM) velocity. 


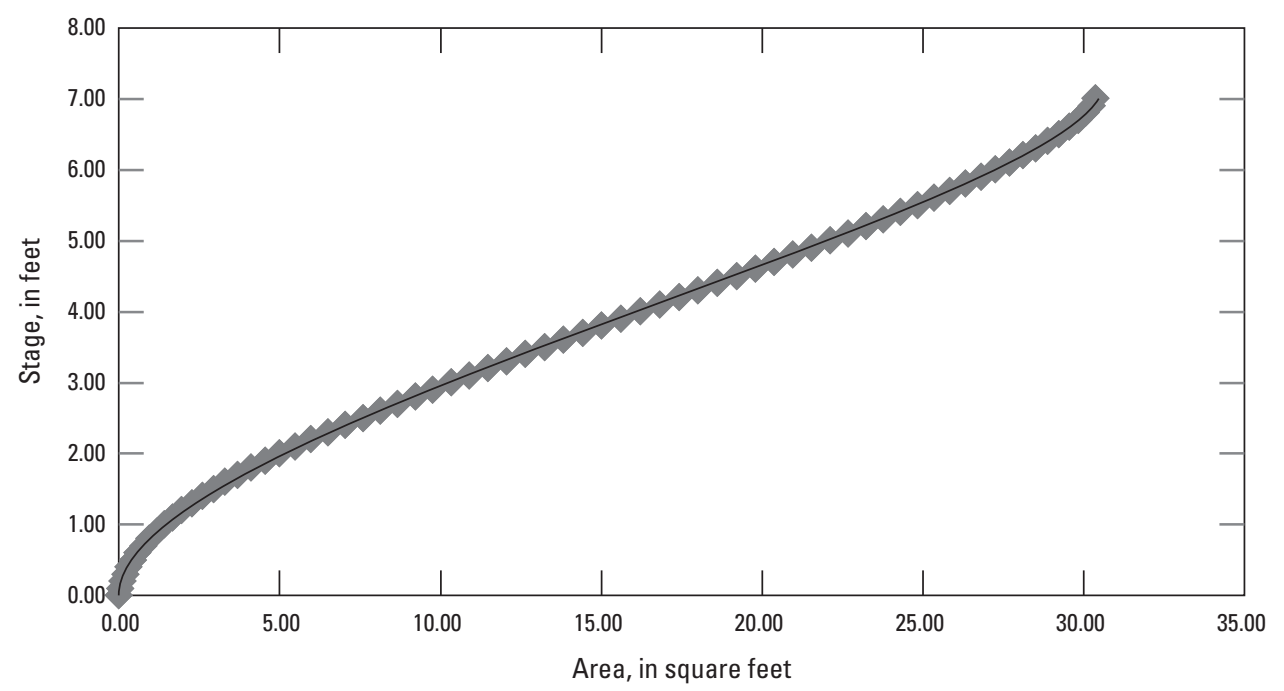

Figure 8. The stage-area rating curve developed from equations 3 and 4 from the channel geometry in figure 7.

\section{Data Accuracy and Limits}

Based on the data collected at the Summit Conduit stream gaging station, mean daily discharge records are considered fair (that is, 95 percent of mean daily discharges within \pm 15 percent of actual) by USGS guidelines (Novak, 1985). This excludes mean daily discharges that are estimated, which are considered poor (that is, 95 percent of mean daily discharges within \pm 20 percent of actual). Currently, daily mean discharges greater than $10 \mathrm{ft}^{3} / \mathrm{s}$ also are rated poor, because of lack of manual measurements collected at high flows to verify computed discharges calculated from the current velocity rating.

Various factors contribute to the difficult monitoring conditions at the Summit Conduit stream gaging station, which have resulted in this rating. The small drainage area and the industrial nonpermeable surfaces present throughout the drainage area result in short lived, flashy events that are difficult measure. Travel time involved in getting personnel to the site and deployment of measurement equipment are prohibitive for capturing short lived events on a regular basis. The nonstandard site conditions with two tributaries converging immediately upstream from the conduit opening limit the places where discharge measurements can be made. The trash rack and walkway cause cavitation and air entrainment into the water that lead to loss of acoustic signal in the water and affect the measurement equipment. Outfall of the conduit is below a steep and unstable bank and the discharge flows onto a short concrete apron then directly into the CSSC. The tributaries also tend to carry a large quantity of woody debris and trash that clog the trash rack and settle to the bottom of the conduit, burying the meter. This has led to a relatively high amount of missing data compared to most gaging stations of a similar deployment. As a result, mean daily discharges for 89 days in water year 2011 and 32 days in water year 2012 were estimated. A water year is defined as the 12-month period October 1, for any given year through September 30, of the following year. The water year is designated by the calendar year in which it ends and which includes 9 of the 12 months. Thus, the year ending September 30, 2011 is called the "2011" water year. The next section offers further explanation of the non-standard site specific conditions at the Summit Conduit stream gaging station.

\section{Site Specific Data Limitations}

\section{Drainage Area}

Summit Conduit has a drainage area of approximately $5.4 \mathrm{mi}^{2}$. This drainage area is smaller than but similar in size to three nearby gaging stations, Tinley Creek near Palos Park, Illinois (05536500), Midlothian Creek at Oak Forest, Illinois (05536340), and Sawmill Creek near Lemont, Illinois (05533400). The drainage area for these three USGS stream gages is $11.2,12.6$, and $13.0 \mathrm{mi}^{2}$ respectively. These three gages are also in the southern part of the greater Chicago area and encounter similar weather patterns. Summit Conduit drainage basin has approximately $2.5 \mathrm{mi}^{2}$ of residential area that includes a $0.2 \mathrm{mi}^{2}$ golf course; the remaining $2.9 \mathrm{mi}^{2}$ is primarily industrial and rock quarry area. The other three nearby comparison drainage areas have substantially more 
residential and forested area and little industrial drainage. The difference in percentages of forested compared to industrial area could account for the lower base flows at the comparison sites, because of phreatic uptake from vegetation in the riparian areas. Peak flow events at Summit Conduit are generally short lived depending on the duration and intensity of the precipitation, and last from as little as a few hours to a couple of days.

\section{Debris Accumulation}

The ADVM is mounted to the bottom of the conduit and is therefore susceptible to being covered up by debris, which blocks the acoustic transducers of the ADVM. This results in temporary loss of data until the debris is removed from the ADVM either by a hydrographer or a larger flow event. Although debris accumulation is inherent with this type of ADVM, debris has only been discovered and removed during the routine periodic visits because the gage was operated without telemetry until October 12, 2012, when a data collection platform (DCP) with a GOES satellite radio was installed. An example of this type of data loss can be seen during the period from February 23 to 27 and again on March 7 and 8, 2011(fig. 9). In figure 9, the times when the signal to noise ratio (SNR) drops somewhere in the range of 50 decibels (dB) or below it is indicative of debris accumulating on the meter blocking or at least dampening the acoustic signal. Thus with a dampened or blocked signal the Doppler SNR drops resulting in compromised computed velocity and stage data. Drops in data are followed by a spike or rise in flow that appears to have scoured the debris from the meter. There are six small events that effectively cleaned the ADVM between hydrographer visits during the period shown in figure 9 .

\section{Computed Discharge}

Computed discharge during low flow (that is, less than $1 \mathrm{ft}^{3} / \mathrm{s}$ ) may contain additional random errors at the Summit Conduit stream gaging station. The errors may be a result of shallow depths of water above the ADVM transducer face that approach the limits of the instrument accuracy. At low flows relatively small differences between measured discharge and rated discharge can result in large percentage differences. These differences have been observed at low flow discharges computed at this site using the index-velocity method and manually measured discharges. This is likely caused by the accuracy limitations of velocity measurement by the ADVM at low velocity (less than $0.25 \mathrm{ft} / \mathrm{s}$ ). At these velocities, the standard error of velocity is approximately $0.07 \mathrm{ft} / \mathrm{s}$ for the given site conditions. This amount of standard error can produce differences in measured and computed discharges of as much as 20 percent during periods of low flow.

A series of three hydrographs of water years 2011 and 2012 showing the daily mean value discharge for Summit Conduit and the three comparison stations indicate that the Summit Conduit base flows are greater than the other sites for a substantial amount of the time during dry weather flow conditions (fig. 10). Hydrographic comparison between nearby stream gages shows they are well matched in terms of event response. The magnitude of events is larger with greater drainage area and smaller with the Summit Conduit. Despite the similar drainage area and weather patterns that effect precipitation, at base flow the hydrographs and associated discharge do not compare as well as expected. This base flow difference is likely because of the presence of artificial drainage from the NPDES permitted discharge and may have a contribution due to a high percentage of impermeable industrial land surface area in the Summit Conduit watershed. Rapid rises in stage generally follow rainfall events and then flows return to near base flow very quickly - usually over a period of hours.

In water years 2011 and 2012, Summit Conduit discharge exceeded the base-flow discharge observed at Tinley Creek near Palos Park 352 of 731 days (48.2 percent), at Midlothian Creek at Oak Park 348 of 731 days (47.6 percent), and at Sawmill Creek near Lemont 513 of 731 days (70.2 percent). Daily value discharge tables that were used to create the plots and determine the percent flow exceedance are provided in appendix 2 for each water year and each site. Even though the base flow for Summit Conduit exceeds the base flow of the other three sites nearly 50 percent of the time, the event driven discharge effectively brings the mean annual discharge for each of these sites back into perspective of their respective drainage areas. In table 1, the computed mean annual discharge for water years 2011 and 2012 are proportionally larger for the larger drainage area sites.

Table 1. Mean annual discharge for water years 2011 and 2012 for Summit Conduit stream gaging station and three comparison stream gaging stations.

[A water year is defined as the 12-month period October 1, for any given year through September 30, of the following year. The water year is designated by the calendar year in which it ends and which includes 9 of the 12 months. Thus, the year ending September 30, 2011 is called the "2011" water year]

\begin{tabular}{|c|c|c|c|c|}
\hline \multirow[b]{2}{*}{ Water year } & \multicolumn{4}{|c|}{ Mean annual discharge, in cubic feet per second } \\
\hline & Summit Conduit & $\begin{array}{c}\text { Tinley Creek } \\
\text { (05536500) }\end{array}$ & $\begin{array}{c}\text { Midlothian Creek } \\
(05536500)\end{array}$ & $\begin{array}{c}\text { Sawmill Creek } \\
(05533400)\end{array}$ \\
\hline 2012 & 6.39 & 10.8 & 11.3 & 7.73 \\
\hline
\end{tabular}


FileName: SUMCD004.arg (Argonaut- SW 3000 kHz)
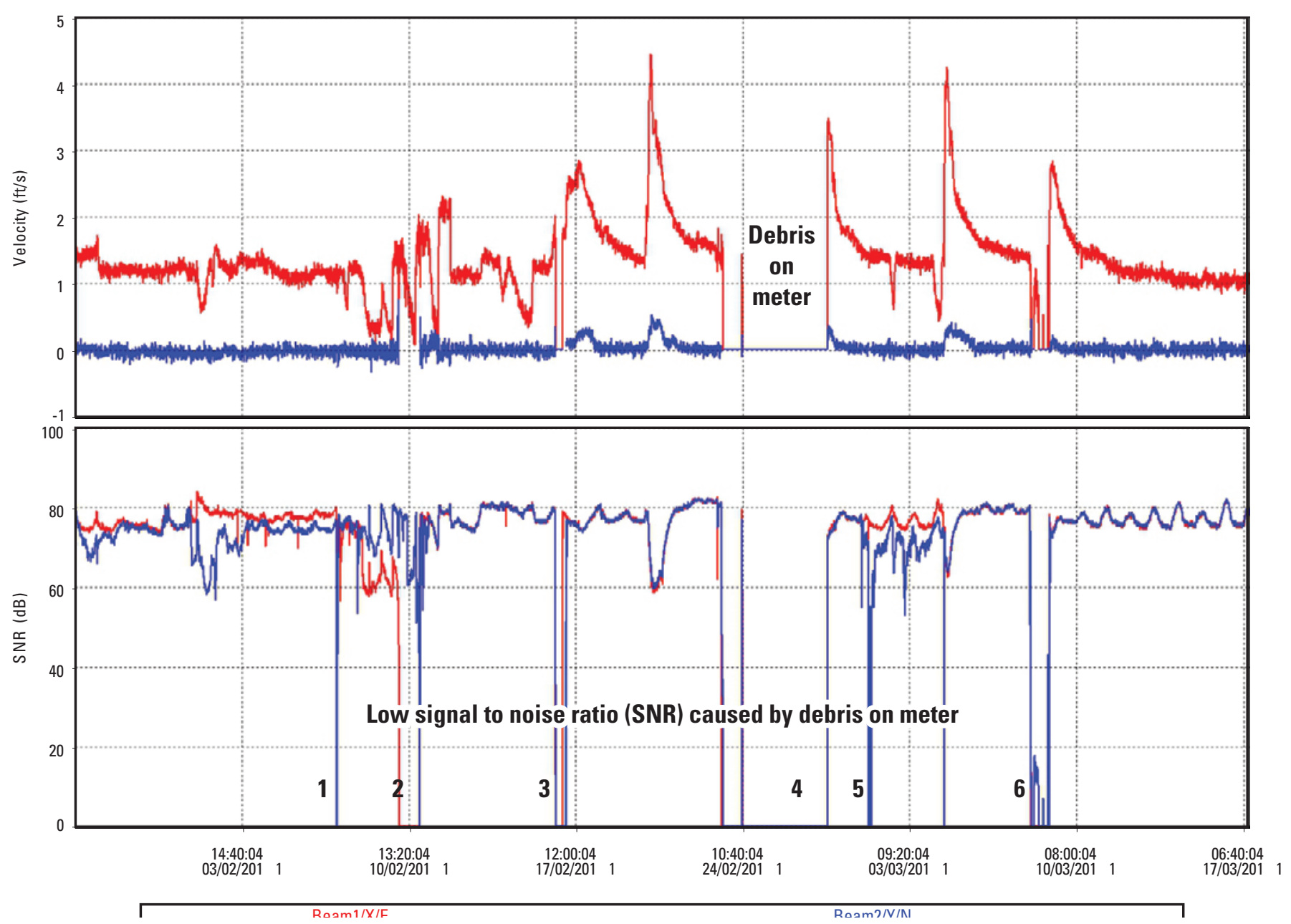

Figure 9. Plot of acoustic Doppler velocity meter (ADVM) data illustrating a period when debris covered the meter, January 27 to March 17, 2011. The numbers on the plot represent a debris deposition event. 

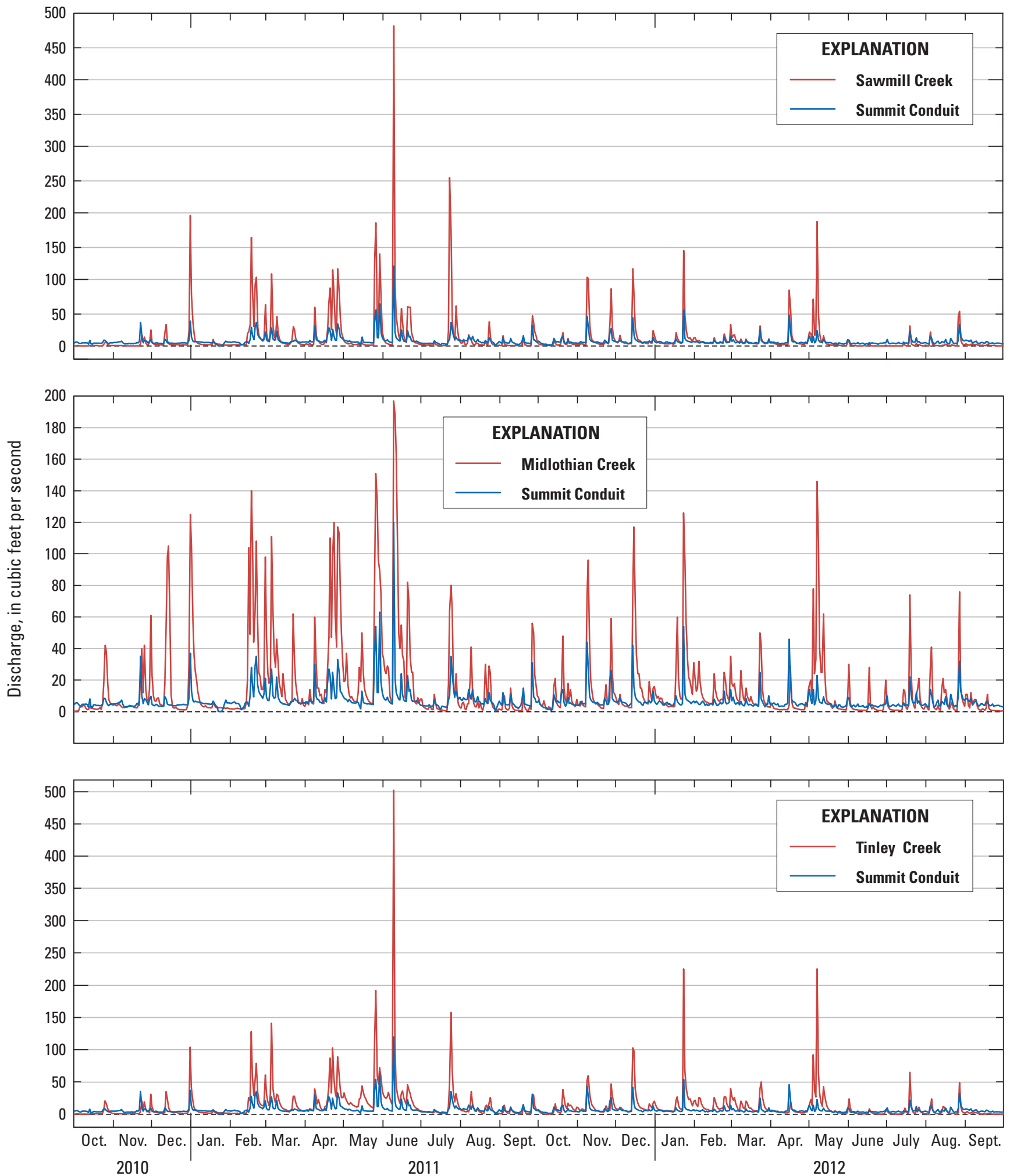

Figure 10. Hydrograph of water years 2011 and 2012 showing Summit Conduit at Summit, Sawmill Creek near Lemont, Midlothian Creek near Oak Park, and Tinley Creek near Palos Hills. 


\section{Data Loss}

Data loss has occurred at low and high flows at the Summit Conduit stream gaging station. Losses of stage and velocity data have occurred during high flow events where water levels have approached or reached the ceiling of the conduit. Although an event resulting in high flow data loss has not been physically observed, it can be inferred that this occurs because of the increased sediment load, debris, aeration, or turbulence because of the change in flow dynamics as a result of increased velocities. The trash rack near the opening of the conduit likely causes air to become entrained in the water column, which may cause interference in the acoustic signals used to measure stage and velocity by the ADVM. Examples of these high flow data losses can be seen during the five events shown in figure 11 between June 9 and 24, 2011.

Because of the relatively short time period that this gaging station has been operated it cannot be determined how often this type of data loss will occur during high flow events. Some events show little sign of signal to noise reduction or loss and yet other events have loss of signal. Thirteen of 52 events reported some type of problem at Summit Conduit during this 2-year period. The cause of each problem is likely one or more of the issues noted previously. Relocation of the ADVM farther into the conduit, or an alternate method for measuring high stages and velocities may be necessary to reduce the number of lost events. The addition of telemetry has already helped to reduce the number of days with bad data.

\section{Future Stream Gaging}

Several improvements have been made through the 2 years that the Summit Conduit stream gage has been operating. The gage improvements have resulted in less data loss because of instrument problems, more quantifiable discharge values for the permanent record, a more robust discharge value to be used in LMDA, and a better understanding of the nonstandard site characteristics that were associated with early efforts to monitor discharge at this site. On March 1, 2013, the ADVM and all gaging equipment were temporarily removed from the Summit Conduit. This was done to accommodate the construction of a new lining within the entire conduit. The MWRD hired a contractor to line the conduit with a mortar and vinyl lining. The wing walls of the inlet and outfall also are being refurbished. The construction is projected to begin between March and July 2013. Near completion and before water is allowed to resume flowing through the conduit, detailed geometric measurements will be made in the vicinity of where the ADVM will be mounted. The ADVM will be mounted 35 to $40 \mathrm{ft}$ inside the conduit in an effort to reduce the amount of aeration from the trash rack and the additional $20 \mathrm{ft}$ into the conduit also may be less prone to settling debris. The DCP with the GOES transmitter will be reinstalled for real-time data transmission and the instrument configuration for the ADVM will remain as it was prior to removal. Because of the relining of the conduit the stage-area rating and the velocity-velocity ratings will have to be reestablished. This will take time; however the lessons learned from the first 2 years are valuable for the improvement of the site setup and the records computation.

\section{Summary}

LMDA is the process used by the USACE to quantify the amount of water that is diverted from the Lake Michigan watershed into the Illinois and Mississippi River Basins. A network of streamgages within the Chicago area waterway system monitor tributary river flows and the major river flow on CSSC near Lemont as one of the instrumental tools used for LMDA. The mean annual discharges recorded by these streamgages are used as additions or deductions to the mean annual discharge recorded by the main stream gaging station currently used in the LMDA process, which is the CSSC near Lemont, Illinois (station number 05536890).

A new stream gaging station, Summit Conduit near Summit, Illinois (station number 414757087490401), was installed on September 23, 2010, for the purpose of monitoring stage, velocity, and discharge through the Summit Conduit for the USACE in accordance with LMDA. Summit Conduit conveys flow from a small part of the lower Des Plaines River watershed underneath the Des Plaines River directly into the CSSC. Because the Summit Conduit discharges into the CSSC upstream from the stream gaging station at Lemont, Ill, but does not contain flow diverted from the Lake Michigan watershed, it is considered a flow deduction to the discharge measured by the Lemont stream gaging station in the LMDA process. This report offers a technical summary of the techniques and methods used for the collection and computation of the stage, velocity, and discharge data at the Summit Conduit near Summit, Ill stream gaging station for a part of the 2011 and 2012 Water Years.

The stream gaging station Summit Conduit near Summit, Illinois (station number 414757087490401) is an example of a nonstandard stream gage. Traditional methods of equating stage to discharge historically were not effective. Examples of the nonstandard conditions include the converging tributary flows directly upstream of the gage; the trash rack and walkway near the opening of the conduit introducing turbulence and occasionally entraining air bubbles into the flow; debris within the conduit creating conditions of variable backwater and the constant influx of smaller debris that escapes the trash rack and catches or settles in the conduit and on the equipment. An ADVM was installed to measure stage and velocity to compute discharge. The stage is used to calculate area based on the stage-area rating. The index-velocity from the ADVM is applied to the velocity-velocity rating and the product of the two rated values is a rated discharge by the index-velocity method. Nonstandard site conditions prevalent at the Summit Conduit stream gaging station generally are overcome through the index-velocity method. Debris on the meter and aeration has continued to be an issue causing data loss. For this reason, 
FileName: SUMCD037.arg (Argonaut- SW 3000 kHz)

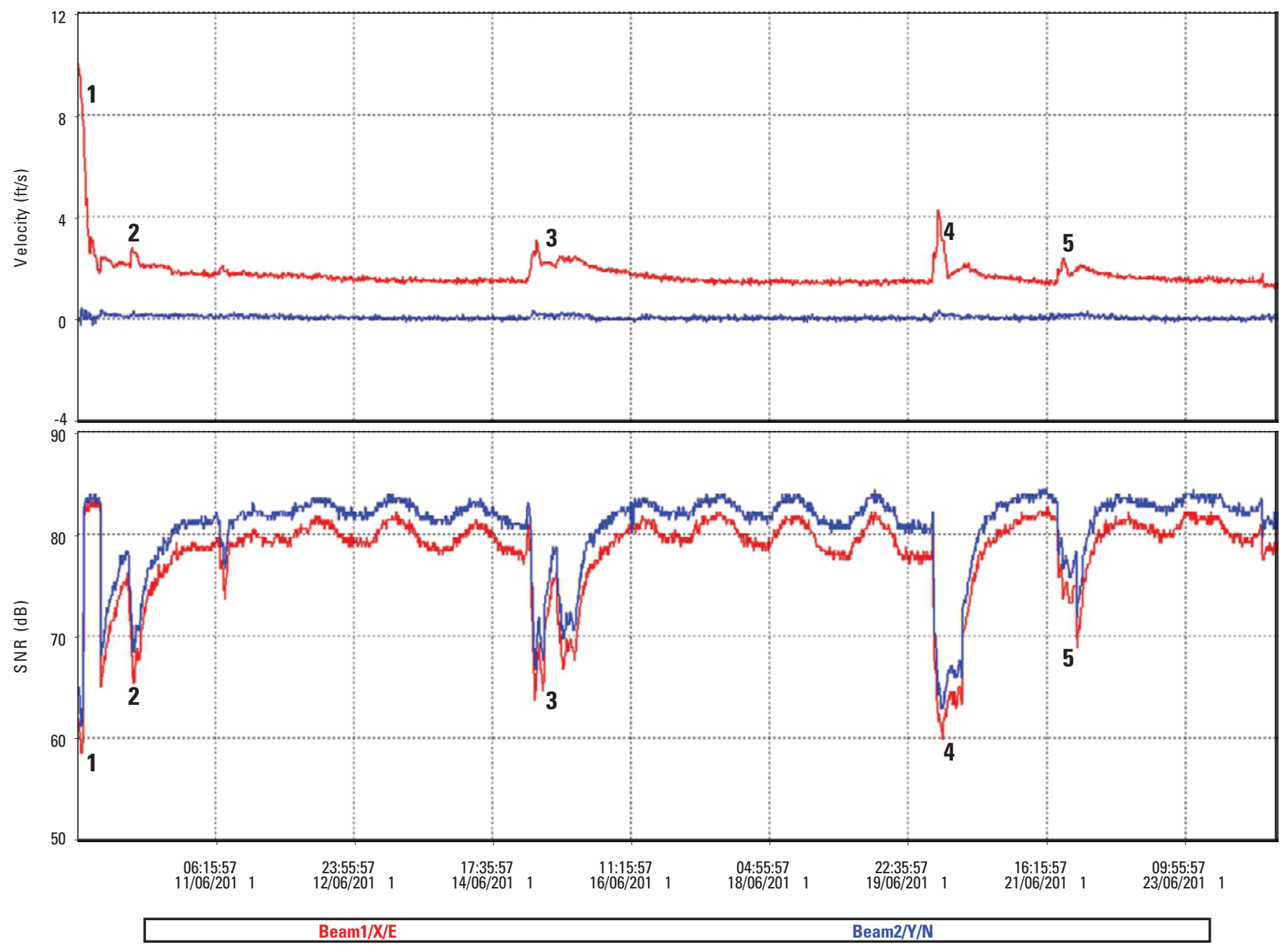

Figure 11. Data lost during five medium to high flow events between June 9 and June 24, 2011. 
daily mean discharge records for this gaging station generally are considered fair by USGS guidelines. Despite the difficulties in gaging and measurements, improvements continue to be made in data collection, transmission, and measurements. Efforts to improve the site and to improve the ratings continue to improve the quality and quantity of the data available for LMDA.

\section{References Cited}

Burke, Christopher B., Engineering Ltd., 2011, Detailed watershed plan for the lower Des Plaines River watershed: v. 1, accessed March 12, 2012, at http://www.mwrd.org/irj/ go/ $/ \mathrm{km} /$ docs $/$ documents/MWRD/internet/protecting_the environment/Stormwater_Management $/ \mathrm{htm} /$ Lower_Des_ Plaines_River_Watershed/Lower_Des_Plaines_River_DWP. htm.

Chow, Ven Te., 1959, Open channel hydraulics: New York, McGraw Hill, 621 p.

Espey, W.H., Barnes, H.H., Jr., and Vigander, S., 1981, Lake Michigan diversion-Findings of the technical committee for review of diversion flow measurements and accounting procedures: U.S. Army Corps of Engineers, Chicago District, 138 p.

Espey, W.H., Barnes, H.H., Jr., and Westfall, D.E., 1987, Lake Michigan diversion-Findings of the second technical committee for review of diversion flow measurements and accounting procedures: U.S. Army Corps of Engineers, Chicago District, 206 p.

Espey, W.H., Lara, O.G., and Barkau, R.L., 1994, Lake Michigan diversion-Findings of the third technical committee for review of diversion flow measurements and accounting procedures: U.S. Army Corps of Engineers, Chicago District, 125 p.

Espey, W.H., Schmidt, A.R.., and Barkau, R. L., 2001, Lake Michigan diversion, Findings of the fourth technical committee for review of diversion flow measurements and accounting procedures: U.S. Army Corps of Engineers, Chicago District, 117 p.

Espey, W.H., Melching, C.S., and Mades, D.M., 2004, Lake Michigan diversion-Findings of the fifth technical committee for review of diversion flow measurements and accounting procedures: Chicago, Illinois, U.S. Army Corps of Engineers, Chicago District, $181 \mathrm{p}$.

Espey, W.H., Melching, C.S., and Muste, M., 2009, Lake Michigan diversion-Findings of the sixth technical committee for review of diversion flow measurements and accounting procedures: U.S. Army Corps of Engineers, Chicago District, 162 p.
Jackson, P.R., Johnson, K.K., and Duncker, J.J., 2012, Comparison of index velocity measurements made with a horizontal acoustic Doppler current profiler and a three-path acoustic velocity meter for computation of discharge in the Chicago Sanitary and Ship Canal near Lemont, Illinois: U.S. Geological Survey Scientific Investigations Report 2011-5205, 42 p.

Johnson, K.K., Duncker, J.J., and Jackson, P.R., 2012, The role of the U.S. Geological Survey in Lake Michigan diversion accounting in Illinois, 1984-2010: U.S. Geological Survey Open-File Report 2012-1243, 84 p.

Kollias, Louis, 2008, Description of the Chicago waterway system for the use attainability analysis, Metropolitan Water Reclamation District of Greater Chicago Report No. 08-15R: 29 p.

Levesque, V.A., and Oberg, K.A., 2012, Computing discharge using the index velocity method: U.S. Geological Survey Techniques and Methods, book 3, chap. A23, 148 p. (Also available at $h t t p: / / p u b s . u s g s . g o v / t m / 3 a 23 /$.

Lindeburg, Michael, R., 1992, Engineer in training reference manual, (8th): Professional Publication, Inc.

Novak, Charles, E., 1985, WRD data reports preparation guide: U.S. Geological Survey Water-Resources Division, USGS Open-File Report 85-480, 199 p.

Rantz, S.E., and others, 1982, Measurement and computation of streamflow-Volume 2, Computation of discharge: U.S. Geological Survey Water-Supply Paper 2175, 631 p.

Sauer, V.B., and Turnipseed, D.P., 2010, Stage measurement at gaging stations: U.S. Geological Survey Techniques and Methods, book 3, chap. A7, 45 p. (Also available at http://pubs.usgs.gov/tm/tm3-a7/.)

Simpson, Michael R., 2001, Discharge measurements using a broad-band Acoustic Doppler current profiler, U.S. Geological Survey Open-File Report 2001-01, 133 p.

SonTek/YSI, Inc., 2006, Argonaut—SW system manual, San Diego, Calif., USA, 279 p.

Turnipseed, D.P., and Sauer, V.B., 2010, Discharge measurements at gaging stations: U.S. Geological Survey Techniques and Methods, book 3, chap. A8, 87 p. (Also available at $h t t p: / / p u b s . u s g s . g o v / t m / t m 3-a 8 /$. )

U.S. Department of Interior Bureau of Reclamation, 2001, Water Resources Research Laboratory-Water Measurement Manual: Washington, D.C. 


\section{Appendix 1.}

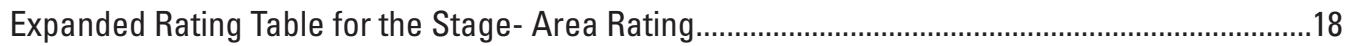

Stage-Area Geometry

.21

\section{Appendix 2. Annual Daily Value Tables for 2011 and 2012}

\section{Summit Conduit near Summit, Illinois (414757087490401)}

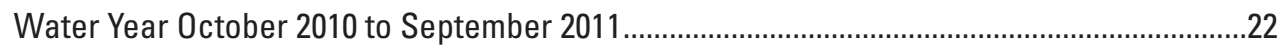

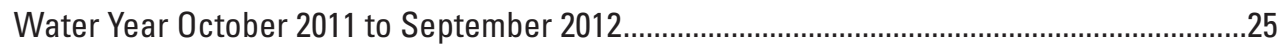

\section{Tinley Creek near Palos Park, Illinois (05536500)}

Water Year October 2010 to September 2011 ……………........................................................28

Water Year October 2011 to September 2012........................................................................31

\section{Midlothian Creek at Oak Park, Illinois (05536340)}

Water Year October 2010 to September 2011........................................................................3

Water Year October 2011 to September 2012.......................................................................3

\section{Sawmill Creek near Lemont, Illinois (05533400)}

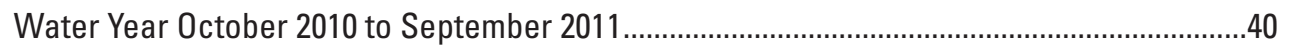

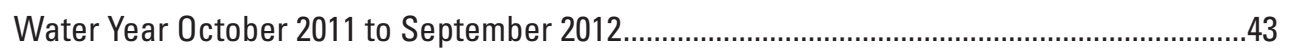


STATION: 414757087490401 Summit Conduit at Summit, IL.

Type: stream, Agency: USGS, State: 17, County: 031, Latitude: 414757, Longitude: 0874904 NAD83,

Drainage area: Contributing drainage area: Datum:

Date processed; 2013-03-07 02:36 By swreview

Rating for Discharge (INFLOW) (cfs)

Rating ID: 1.0, Type: stage-area, Expansion: linear Satus: working

Created by ggoodwin on 06-23-2011 14:50:26 CST, Updated by johnsonk on 03-05-2013 09:38:43 CST

Rating remarks:

EXPANDED RATING TABLE

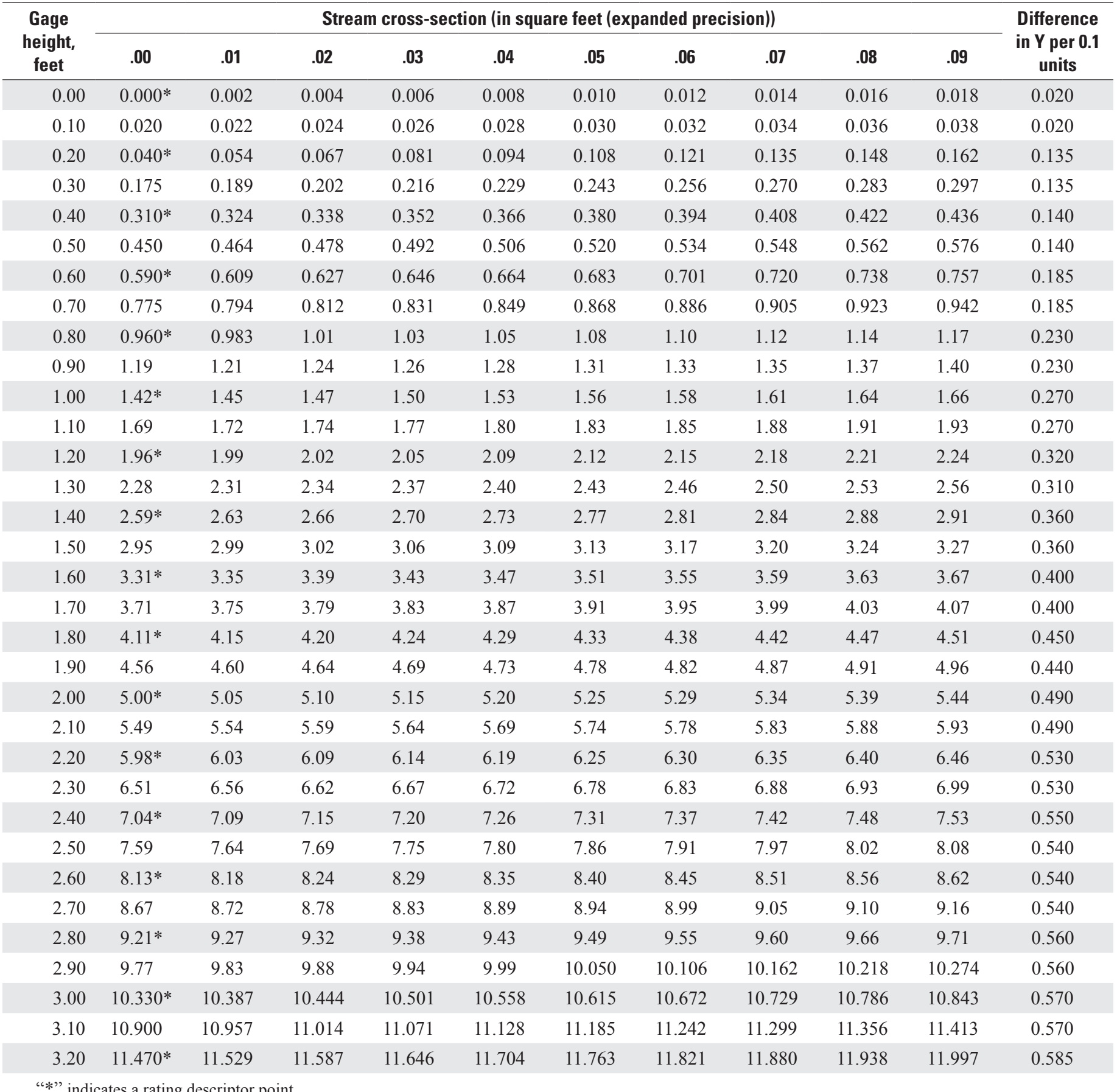




\section{STATION: 414757087490401 Summit Conduit at Summit, IL.-Continued}

Type: stream, Agency: USGS, State: 17, County: 031, Latitude: 414757, Longitude: 0874904 NAD83, Drainage area: Contributing drainage area: Datum:

Date processed; 2013-03-07 02:36 By swreview Rating for Discharge (INFLOW) (cfs)

Rating ID: 1.0, Type: stage-area, Expansion: linear Satus: working

Created by ggoodwin on 06-23-2011 14:50:26 CST, Updated by johnsonk on 03-05-2013 09:38:43 CST

Rating remarks:

EXPANDED RATING TABLE

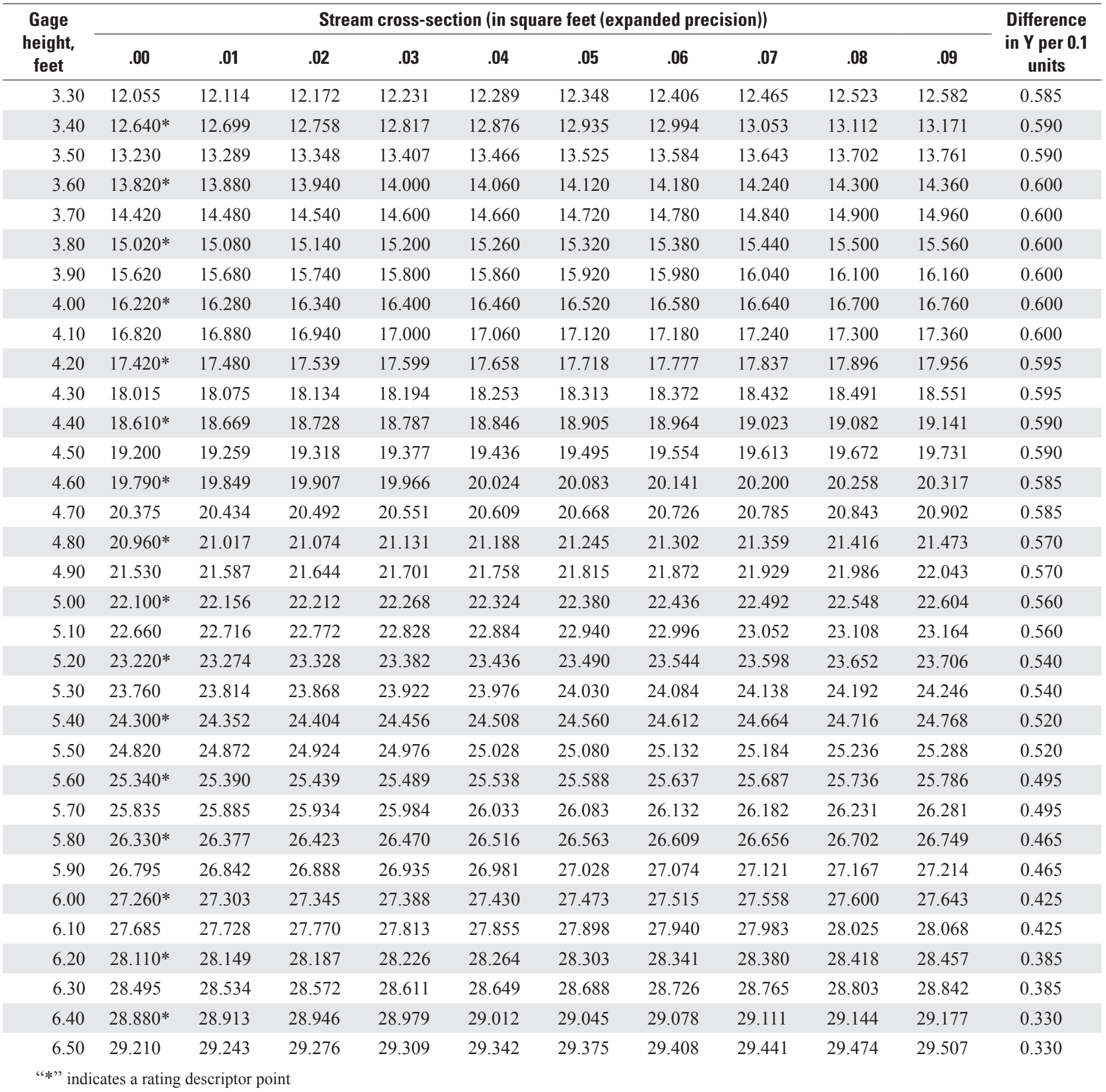


STATION: 414757087490401 Summit Conduit at Summit, IL.-Continued

Type: stream, Agency: USGS, State: 17, County: 031, Latitude: 414757, Longitude: 0874904 NAD83,

Drainage area: Contributing drainage area: Datum:

Date processed; 2013-03-07 02:36 By swreview

Rating for Discharge (INFLOW) (cfs)

Rating ID: 1.0, Type: stage-area, Expansion: linear Satus: working

Created by ggoodwin on 06-23-2011 14:50:26 CST, Updated by johnsonk on 03-05-2013 09:38:43 CST

Rating remarks:

\begin{tabular}{|c|c|c|c|c|c|c|c|c|c|c|c|}
\hline \multicolumn{12}{|c|}{ EXPANDED RATING TABLE } \\
\hline \multirow{2}{*}{$\begin{array}{c}\text { Gage } \\
\text { height, } \\
\text { feet }\end{array}$} & \multicolumn{10}{|c|}{ Stream cross-section (in square feet (expanded precision)) } & \multirow{2}{*}{$\begin{array}{c}\text { Difference } \\
\text { in } Y \text { per } 0.1 \\
\text { units }\end{array}$} \\
\hline & .00 & .01 & .02 & .03 & .04 & .05 & .06 & .07 & .08 & .09 & \\
\hline 6.60 & $29.540^{*}$ & 29.566 & 29.592 & 29.618 & 29.644 & 29.670 & 29.696 & 29.722 & 29.748 & 29.774 & 0.260 \\
\hline 6.70 & 29.800 & 29.826 & 29.852 & 29.878 & 29.904 & 29.930 & 29.956 & 29.982 & 30.008 & 30.034 & 0.260 \\
\hline 7.00 & $30.350 *$ & 30.355 & 30.360 & 30.365 & 30.370 & 30.375 & 30.380 & 30.385 & 30.390 & 30.395 & 0.050 \\
\hline 7.10 & 30.400 & 30.405 & 30.410 & 30.415 & 30.420 & 30.425 & 30.430 & 30.435 & 30.440 & 30.445 & 0.050 \\
\hline 7.20 & $30.450 *$ & & & & & & & & & & \\
\hline
\end{tabular}

"*", indicates a rating descriptor point

Rating Type:

$\begin{array}{ll}\text { ID } & \text { Starting Date } \\ 1.0 & 09-23-2010 @ 12: 00: 00 \text { CST }\end{array}$
Rating type: stage-area

Ending Date 


\section{Stage-Area Geometry}

\section{Reference Calcuations}

Culvert Dimensions

D $\quad 6.00 \mathrm{ft}$

$6.00 \mathrm{ft}$
$3.00 \mathrm{ft}$

pipe diameter

$\begin{array}{ll}r_{-} & 3.00 \mathrm{ft} \\ y_{-1} & 2.50 \mathrm{ft}\end{array}$

y_2 $\quad 7.00 \mathrm{ft}$

b $\quad 0.33 \mathrm{ft}$

zAngle $\quad 42.70 \mathrm{deg}$

$z \quad 1.08 \mathrm{ft}$

Computed Constants

$\begin{array}{lll}\text { TA } & 7.61 \mathrm{ft}^{\wedge} 2 & \text { full trapezoid area } \\ \mathrm{CA} & 5.53 \mathrm{ft}^{\wedge} 2 & \text { area of circular segment overlap (stipled line) } \\ \text { r2 } & 1.50 \mathrm{ft} & \text { dist from top of trapezoid to base of pipe } \\ \text { r3 } & 1.00 \mathrm{ft} & \text { dist from bottom to bottom of pipe }\end{array}$

dist from bottom to bottom of pipe

\section{Description of Conduit Geometry}

The conduit is a compound shape, consisting of a pipe with diameter $\left(r_{-}\right)$and a trapezoid of height (y_1), bottom width (b), and side wall slope (zAngle). The pipe and trapezoid overlap for a distance along the radius $\left(r_{-}\right)$of $\left(\_r 2\right)$.

\begin{tabular}{|c|c|c|c|}
\hline step & solve for & if flow depth < radius & if flow depth $\geq$ radius \\
\hline & & $r$ & \\
\hline 1 & circular segment height & $h=d$ & $h=2 r-d$ \\
\hline 2 & central angle & $\theta=2 \arccos \left(\frac{r-h}{r}\right)$ & $\theta=2 \arccos \left(\frac{r-h}{r}\right)$ \\
\hline 3 & circular segment area & $K=\frac{r^{2}(\theta-\sin \theta)}{2}$ & $K=\frac{r^{2}(\theta-\sin \theta)}{2}$ \\
\hline 4 & arc length & $s=r \times \theta$ & $s=r \times \theta$ \\
\hline 5 & flow area & $A=K$ & $A=\pi^{2}-K$ \\
\hline 6 & wetted perimeter & $P_{W}=S$ & $P_{W}=2 \pi-s$ \\
\hline 7 & hydraulic radius & $R_{h}=\frac{A}{P_{W}}$ & $R_{h}=\frac{A}{P_{W}}$ \\
\hline
\end{tabular}

h_pipe = cicular segment height

theta $\quad=$ central angle

$\mathrm{K}=$ circular segment area

$\mathrm{S} \quad=$ arc length

A_pipe = area contain in pipe

A-pipe $-\mathrm{CA} \quad=$ area in pipe minus segment overlaping trapezoid

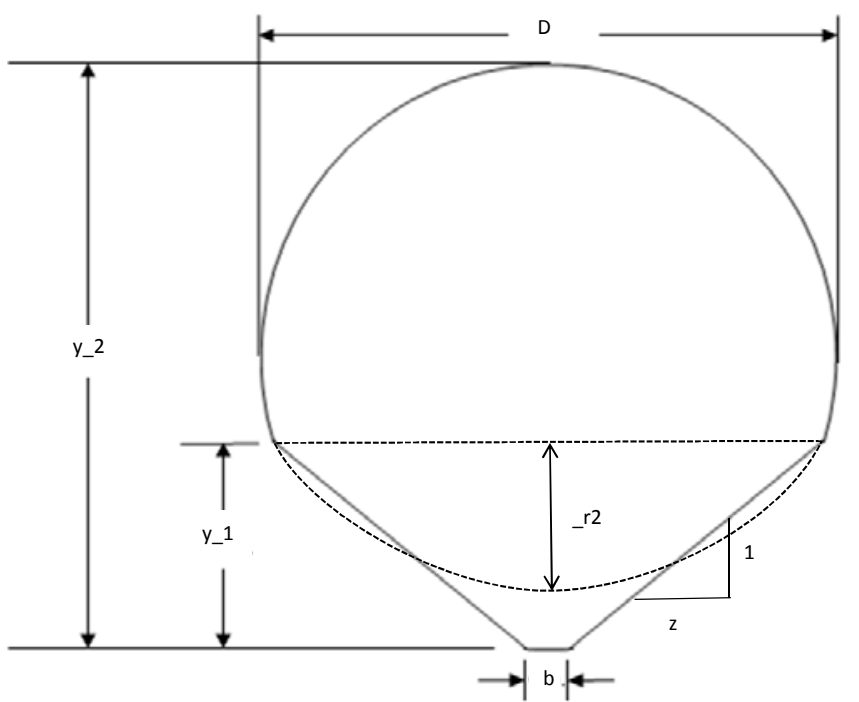

References - Books:

U.S. Department of the Interior Bureau of Reclamation. Water Resources Research Laboratory: Water Measurement Manual. Washington DC, 2001.

Lindeburg, Michael R. 1992. Engineer In Training Reference Manual. Professional Publication, Inc. Sth Edition. 
STATION: 414757087490401 Summit Conduit at Summit, IL

Type: stream, Agency: USGS, State: 17, County: 031, Latitude: 414757, Longitude: 0874904 NAD83, Drainage area:

Contributing drainage area: Datum:

Date processed; 2013-04-11 23:58 By swreview

Lowest aging status in period is APPROVED

DD \#3, (INFLOW)

Discharge, cubic feet per second

WATER YEAR OCTOBER 2010 TO SEPTEMBER 2011

DAILY MEAN VALUES

\begin{tabular}{|c|c|c|c|c|c|c|c|c|c|c|c|c|}
\hline Day & Oct & Nov & Dec & Jan & Feb & Mar & Apr & May & Jun & Jul & Aug & Sep \\
\hline 1 & 5.6 & e4.9 & 5.3 & 14 & 5.6 & 9.8 & 6.9 & e8.9 & 9.8 & 4.5 & e7.6 & 5.9 \\
\hline 2 & 6.4 & e5.0 & 4.7 & 7.9 & 6.1 & 7.8 & 6.0 & e8.0 & 8.2 & 4.2 & e7.2 & 4.6 \\
\hline 4 & 5.4 & e5.4 & 5.3 & $\# 6.5$ & 6.7 & 16 & e7.9 & e6.3 & 9.7 & 4.2 & 8.4 & 7.1 \\
\hline 5 & 4.5 & 6.8 & 5.1 & e6.3 & 5.7 & 26 & e6.3 & e7.7 & 7.7 & 4.1 & 7.9 & 5.2 \\
\hline 7 & 5.5 & 8.2 & 4.2 & e5.9 & 5.6 & 9.2 & e6.5 & 6.4 & 5.6 & 4.8 & 14 & 4.9 \\
\hline 8 & 5.4 & 5.6 & 4.1 & e5.7 & 4.8 & $\# 8.5$ & 29 & 6.2 & 5.6 & 3.9 & 11 & 5.0 \\
\hline 9 & 5.5 & 3.8 & 4.0 & e5.5 & 1.8 & $\# 21$ & 10 & 6.1 & e120 & 4.0 & 8.6 & \#5.8 \\
\hline 10 & 5.6 & 3.7 & 4.2 & e5.3 & 2.4 & 10 & 8.3 & 5.8 & 21 & 4.0 & \#5.9 & e6.0 \\
\hline 11 & 5.3 & 4.0 & 10 & e5.1 & 2.7 & 8.0 & 8.0 & 6.9 & 13 & $\# 8.0$ & e7.0 & e4.8 \\
\hline 15 & 3.6 & 4.4 & 4.9 & e4.9 & 4.2 & 5.4 & 7.6 & \#11 & e24 & 2.8 & 7.4 & $\mathrm{e} 2.0$ \\
\hline 16 & 5.2 & 4.1 & 4.8 & e4.7 & $\# 8.6$ & 5.3 & 9.3 & 6.7 & 12 & 2.2 & 6.6 & $\# 4.5$ \\
\hline 17 & 5.2 & 4.2 & 4.6 & e4.8 & 28 & 5.2 & 6.7 & 5.9 & 7.8 & 3.8 & 5.4 & 4.7 \\
\hline 18 & 5.0 & 4.6 & 4.4 & e6.7 & 16 & 4.9 & 18 & 5.8 & 7.1 & 3.8 & 5.5 & 8.3 \\
\hline 19 & 4.8 & 6.1 & 4.4 & $\# 6.2$ & 9.9 & 4.7 & 27 & 5.5 & 6.9 & 3.5 & 5.1 & 16 \\
\hline 20 & 4.8 & 5.5 & 4.4 & 4.5 & e29 & 6.9 & 23 & 5.6 & e23 & 3.2 & \#7.8 & 5.5 \\
\hline 21 & 4.8 & 8.1 & 4.9 & 3.9 & e35 & 7.4 & 8.8 & 5.5 & $\# 8.5$ & 2.9 & 6.4 & 5.2 \\
\hline 22 & 4.9 & e35 & 4.9 & 0.78 & \#11 & 7.2 & 24 & 5.4 & \#11 & e7.2 & 5.7 & 4.7 \\
\hline 29 & e4.7 & 8.2 & 4.9 & 6.2 & --- & 6.0 & \#11 & \#59 & 5.8 & e9.9 & 2.9 & e6.0 \\
\hline 30 & $\mathrm{e} 4.8$ & 10 & 9.2 & 6.1 & --- & 6.1 & $\mathrm{e} 10$ & 19 & 4.7 & e8.0 & 4.9 & e5.7 \\
\hline 31 & $\mathrm{e} 4.8$ & --- & e37 & 6.1 & --- & 6.0 & --- & 12 & --- & e9.1 & 7.2 & --- \\
\hline Total & 169.7 & 207.8 & 193.7 & 163.72 & 284.5 & 261.5 & 370.1 & 359.4 & 395.2 & 227.6 & 220.26 & 199.8 \\
\hline Mean & 5.47 & 6.93 & 6.25 & 5.28 & 10.2 & 8.44 & 12.3 & 11.6 & 13.2 & 7.34 & 7.11 & 6.66 \\
\hline Max & 9.1 & 35 & 37 & 14 & 35 & 26 & 33 & 59 & 120 & 35 & 14 & 30 \\
\hline Min & 3.6 & 3.7 & 4.0 & 0.61 & 1.8 & 4.7 & 5.6 & 2.2 & 4.7 & 2.2 & 0.86 & 2.0 \\
\hline
\end{tabular}

e is Estimated

\# Value is write-protected with a " 1 " 
STATION: 414757087490401 Summit Conduit at Summit, IL

DD \#3 (INFLOW)

Discharge, cubic feet per second

WATER YEAR OCTOBER 2010 TO SEPTEMBER 2011-Continued

STATISTICS OF MONTHLY MEAN DATA FOR WATER YEARS 1951-2011, BY WATER YEAR (WY)

\begin{tabular}{|c|c|c|c|c|c|c|c|c|c|c|c|c|}
\hline & Oct & Nov & Dec & Jan & Feb & Mar & Apr & May & Jun & Jul & Aug & Sep \\
\hline Mean & 5.47 & 6.93 & 6.25 & 5.28 & 10.2 & 8.44 & 12.3 & 11.6 & 13.2 & 7.34 & 7.11 & 6.66 \\
\hline Max & 5.47 & 6.93 & 6.25 & 5.28 & 10.2 & 8.44 & 12.3 & 11.6 & 13.2 & 7.34 & 7.11 & 6.66 \\
\hline Min & 5.47 & 6.93 & 6.25 & 5.28 & 10.2 & 8.44 & 12.3 & 11.6 & 13.2 & 7.34 & 7.11 & 6.66 \\
\hline (WY) & 2011 & 2011 & 2011 & 2011 & 2011 & 2011 & 2011 & 2011 & 2011 & 2011 & 2011 & 2011 \\
\hline
\end{tabular}

SUMMARY STATISTICS

\begin{tabular}{lcccr}
\hline & For 2011 Water Year & Water Years 2010-2011 \\
\hline Annual total & 3053.28 & & & \\
Annual mean & 8.37 & & 8.37 & \\
Highest annual mean & & & 8.37 & 2011 \\
Lowest annual mean & & & 120 & Jun 92011 \\
Highest daily mean & 120 & Jun 9 & 0.61 & Jan 23 2011 \\
Lowest daily mean & 0.61 & Jan 23 & 2.1 & Jan 20 2011 \\
Annual seven-day minimum & 2.1 & Jan 20 & 220 & Jul 23 2011 \\
Maximum peak flow & 220 & Jul 23 & 7.18 & May 29 2011 \\
Maximum peak stage & 7.18 & May 29 & 0.28 & Aug 28 2011 \\
Instantaneous low flow & 0.28 & Aug 28 & 13 & \\
10 percent exceeds & 13 & & 6.1 & \\
50 percent exceeds & 6.1 & & 4.1 & \\
90 percent exceeds & 4.1 & & & \\
\hline
\end{tabular}


STATION: 414757087490401 Summit Conduit at Summit, IL

Type: stream, Agency: USGS, State: 17, County: 031, Latitude: 414757, Longitude: 0874904 NAD83, Drainage area:

Contributing drainage area: Datum:

Date processed: 2013-04-11 23:58 By swreview

Lowest aging status in period is APPROVED

DD \#1 (INFLOW)

Gage height, feet

WATER YEAR OCTOBER 2010 TO SEPTEMBER 2011

DAILY MEAN VALUES

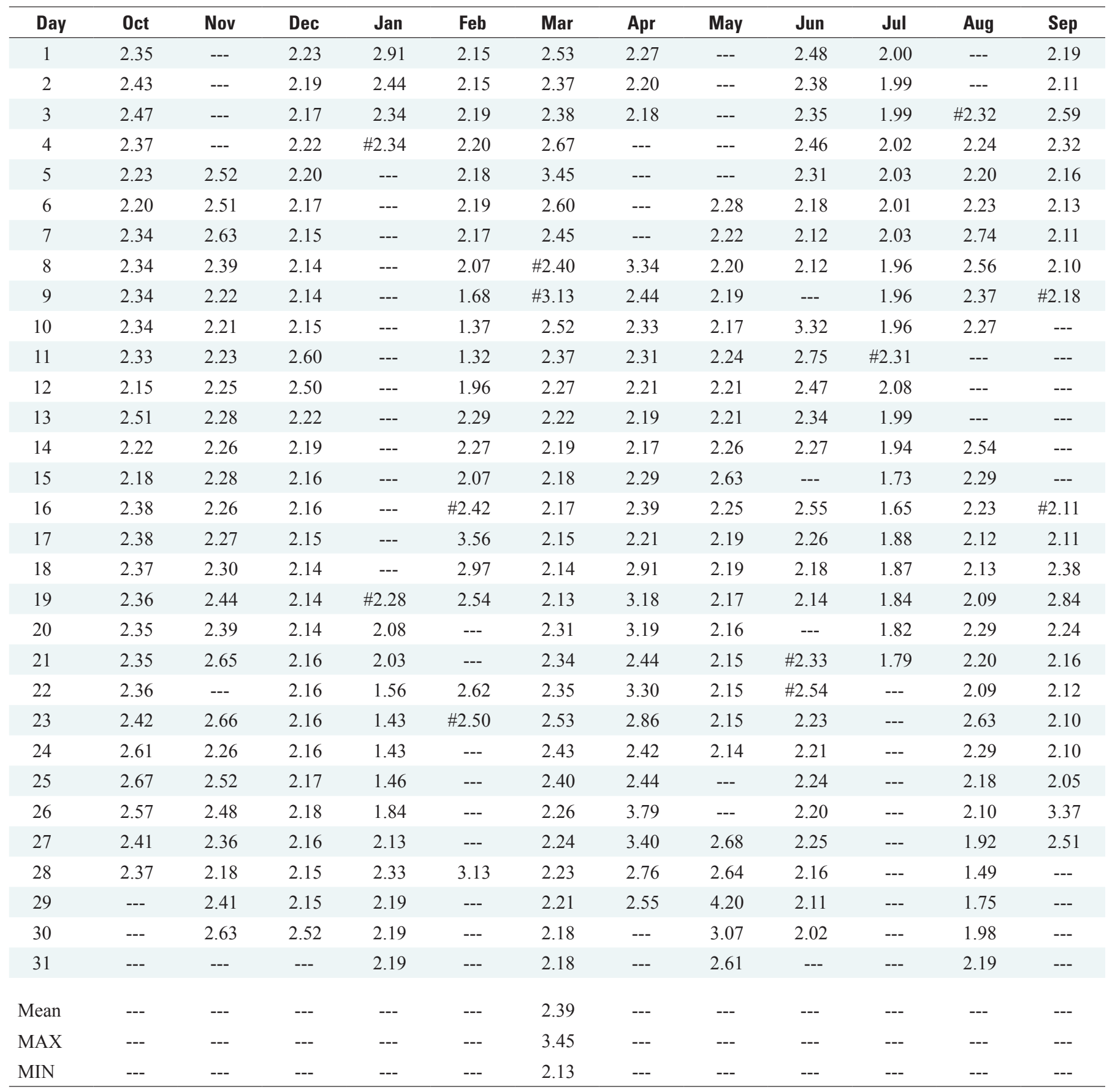

\# Value is write-protected with a "1" 
STATION: 414757087490401 Summit Conduit at Summit, IL

Type: stream, Agency: USGS, State: 17, County: 031, Latitude: 414757, Longitude: 0874904 NAD83, Drainage area:

Contributing drainage area: Datum:

Date processed; 2013-04-12 00:06 By swreview

Lowest aging status in period is APPROVED

DD \#3, (INFLOW)

Discharge, cubic feet per second

WATER YEAR OCTOBER 2011 TO SEPTEMBER 2012

DAILY MEAN VALUES

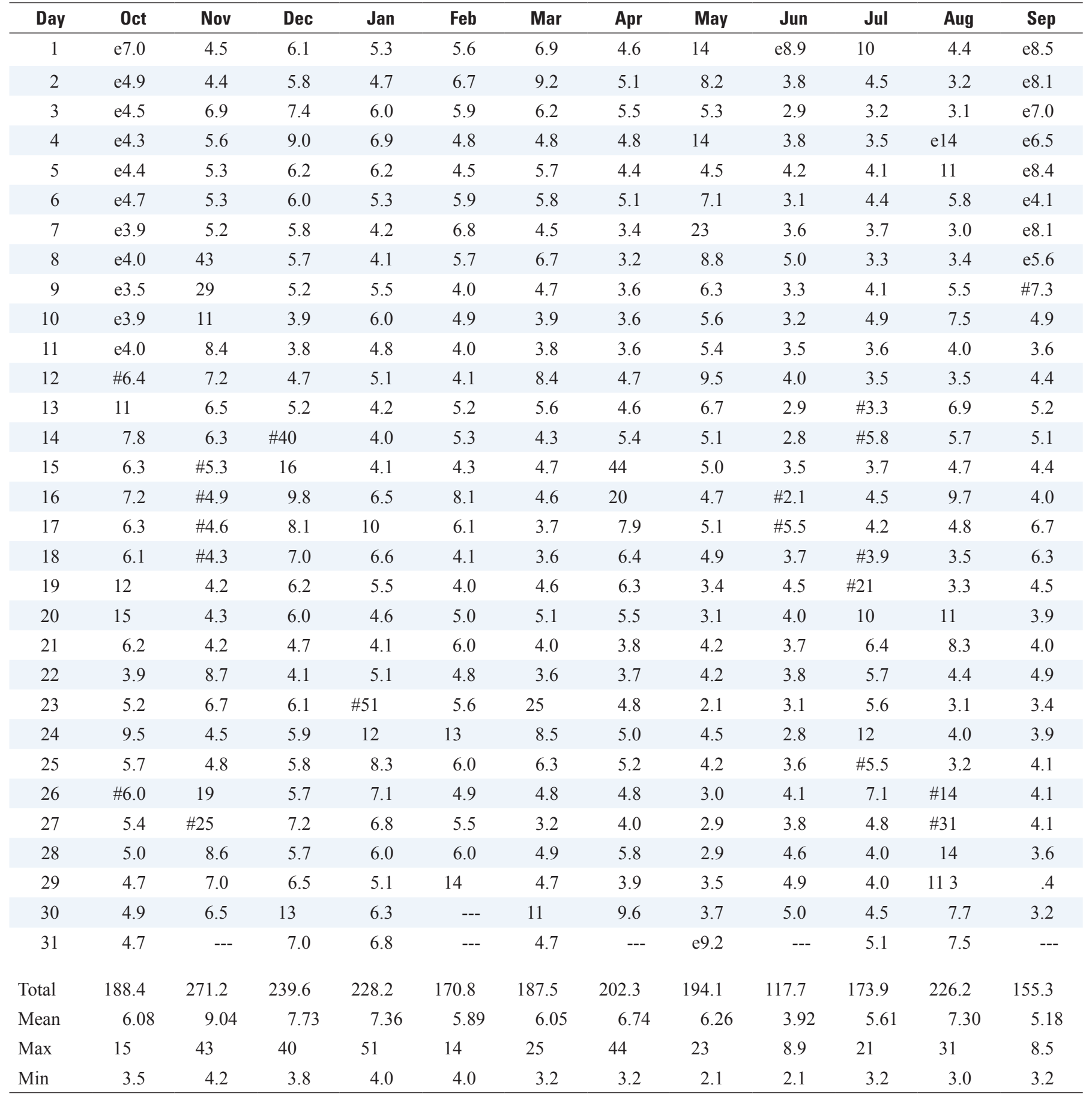

$\mathrm{e}$ is Estimated

\# Value is write-protected with a " 1 " 
STATION: 414757087490401 Summit Conduit at Summit, IL

DD \#3 (INFLOW)

Discharge, cubic feet per second

WATER YEAR OCTOBER 2011 TO SEPTEMBER 2012-Continued

STATISTICS OF MONTHLY MEAN DATA FOR WATER YEARS 1951-2011, BY WATER YEAR (WY)

\begin{tabular}{lccccccccccccc}
\hline & Oct & Nov & Dec & Jan & Feb & Mar & Apr & May & Jun & Jul & Aug & Sep \\
\hline Mean & 5.78 & 7.98 & 6.99 & 6.32 & 7.99 & 7.24 & 9.54 & 8.93 & 8.55 & 6.48 & 7.20 & 5.92 \\
Max & 6.08 & 9.04 & 7.73 & 7.36 & 10.2 & 8.44 & 12.3 & 11.6 & 13.2 & 7.34 & 7.30 & 6.66 & 2011 \\
(WY) & 2012 & 2012 & 2012 & 2012 & 2011 & 2011 & 2011 & 2011 & 2011 & 2011 & 2012 & 2011 \\
Min & 5.47 & 6.93 & 6.25 & 5.28 & 5.89 & 6.05 & 6.74 & 6.26 & 3.92 & 5.61 & 7.11 & 5.18 & 2012 \\
(WY) & 2011 & 2011 & 2011 & 2011 & 2012 & 2012 & 2012 & 2012 & 2012 & 2012 & 2011 & 2012 \\
\hline
\end{tabular}

SUMMARY STATISTICS

\begin{tabular}{|c|c|c|c|c|c|c|}
\hline & \multicolumn{2}{|c|}{ For 2011 Calendar Year } & \multicolumn{2}{|c|}{ For 2012 Water Year } & \multicolumn{2}{|c|}{ Water Years 2010-2012 } \\
\hline Annual total & 3181.28 & & 2355.2 & & & \\
\hline Annual mean & 8.72 & & 6.43 & & 7.40 & \\
\hline Highest annual mean & & & & & 8.37 & 2011 \\
\hline Lowest annual mean & & & & & 6.43 & 2012 \\
\hline Highest daily mean & 120 & Jun 9 & 51 & Jan 23 & 120 & Jun 92011 \\
\hline Lowest daily mean & 0.61 & Jan 23 & 2.1 & May 23 & 0.61 & Jan 232011 \\
\hline Annual seven-day minimum & 2.1 & Jan 20 & 3.1 & Jun 10 & 2.1 & Jan 202011 \\
\hline Maximum peak flow & & & 129 & Apr 15 & & \\
\hline Maximum peak stage & & & 6.75 & Apr 15 & & \\
\hline Instantaneous low flow & & & 0.31 & Jun 16 & & \\
\hline 10 percent exceeds & 14 & & 9.6 & & 11 & \\
\hline 50 percent exceeds & 6.3 & & 5.1 & & 5.6 & \\
\hline 90 percent exceeds & 4.1 & & 3.5 & & 3.7 & \\
\hline
\end{tabular}


STATION: 414757087490401 Summit Conduit at Summit, IL

Type: stream, Agency: USGS, State: 17, County: 031, Latitude: 414757, Longitude: 0874904 NAD83, Drainage area:

Contributing drainage area: Datum:

Date processed: 2013-04-12 00:06 By swreview

Lowest aging status in period is APPROVED

DD \#1 (INFLOW)

Gage height, feet

WATER YEAR OCTOBER 2011 TO SEPTEMBER 2012

DAILY MEAN VALUES

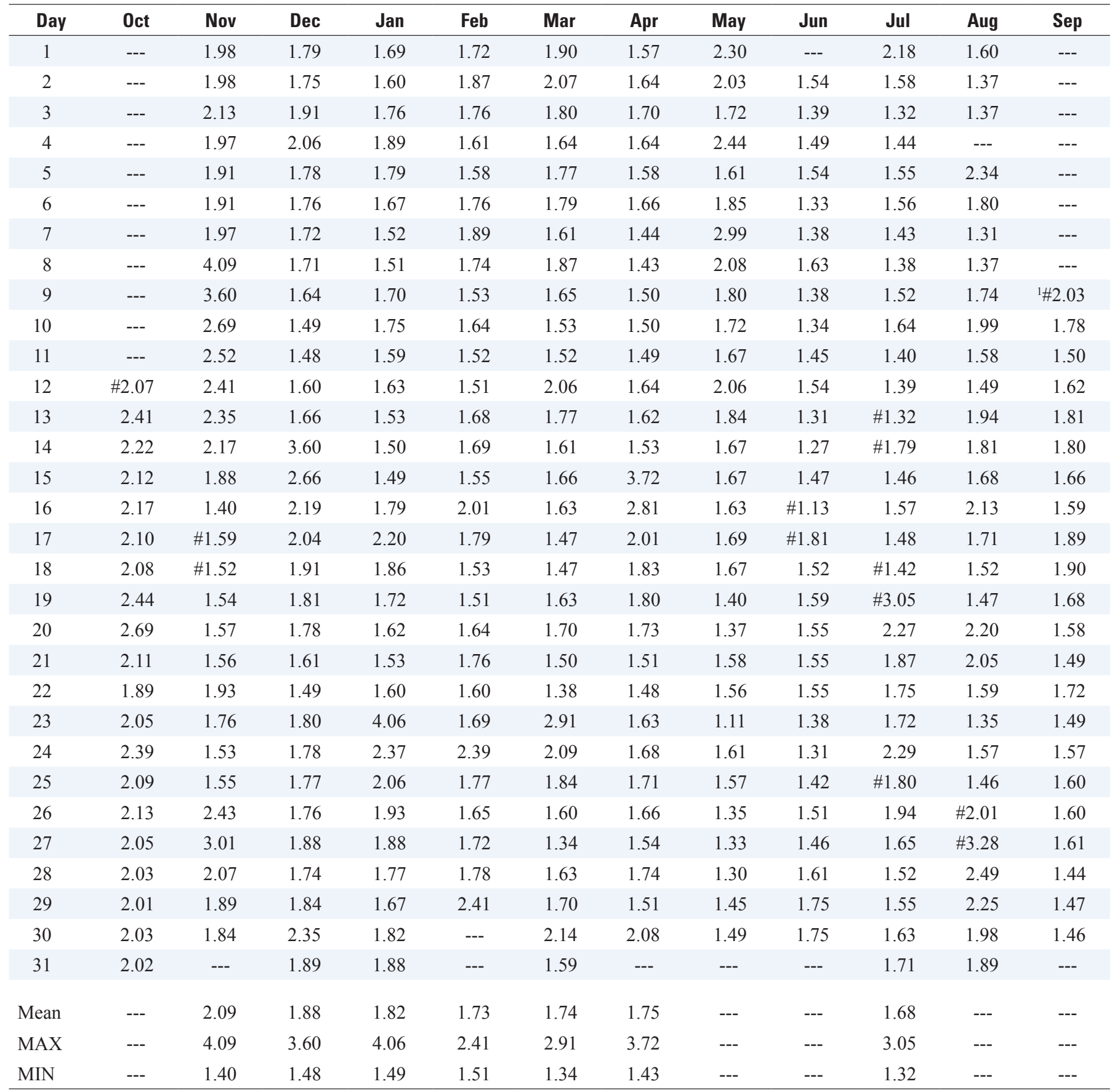

"\# Value is write-protected with a "1" 
STATION: 05536500 Tinley Creek near Palos Park, IL

Type: stream, Agency: USGS, State: 17, County: 031, Latitude: 413848, Longitude: 0874559 NAD27, Drainage area:11.2,

Contributing drainage area:11.20*, Datum: 607.40 NGVD29

Date processed; 2012-01-19 10:31 by adrobl

Lowest aging status in period is APPROVED

DD \#4

Discharge, cubic feet per second

WATER YEAR OCTOBER 2010 TO SEPTEMBER 2011

DAILY MEAN VALUES

\begin{tabular}{|c|c|c|c|c|c|c|c|c|c|c|c|c|}
\hline Day & Oct & Nov & Dec & Jan & Feb & Mar & Apr & May & Jun & Jul & Aug & Sep \\
\hline 1 & 0.30 & 0.99 & 12 & 42 & e1.4 & 31 & 5.1 & 33 & 30 & 4.7 & 6.5 & 0.97 \\
\hline 2 & 0.35 & 0.82 & 5.4 & 22 & e1.3 & 20 & 6.7 & 26 & 26 & 4.3 & 5.1 & 0.83 \\
\hline 4 & 0.50 & 0.87 & 2.8 & 6.5 & e1.3 & 31 & 8.3 & 17 & 27 & 3.6 & 4.4 & 14 \\
\hline 5 & 0.39 & 0.89 & 3.0 & 5.6 & e1.4 & 141 & 8.0 & 15 & 34 & 3.3 & 3.7 & 5.5 \\
\hline 7 & 0.34 & 0.79 & 1.8 & 3.3 & e1.4 & 26 & 5.3 & 16 & 19 & 3.0 & 4.0 & 1.9 \\
\hline 8 & 0.27 & 0.74 & 1.5 & 2.8 & e1.3 & 18 & 39 & 14 & 15 & 3.2 & 10 & 1.3 \\
\hline 9 & 0.20 & 0.87 & 1.3 & 2.6 & $\mathrm{e} 1.2$ & 31 & 27 & 13 & 502 & 2.9 & 35 & 11 \\
\hline 10 & 0.22 & 0.87 & 1.4 & 2.3 & e1.1 & 29 & 16 & 12 & 111 & 2.4 & 17 & 6.8 \\
\hline 11 & 0.26 & 0.89 & 3.2 & 2.2 & $\mathrm{e} 1.2$ & 20 & 23 & 11 & 45 & 3.3 & 8.3 & 3.5 \\
\hline 15 & 1.3 & 0.99 & 5.4 & 1.9 & 26 & 8.0 & 5.8 & 44 & 32 & 2.3 & 4.9 & 0.95 \\
\hline 16 & 0.84 & 1.1 & 4.0 & 1.9 & 21 & 7.4 & 12 & 35 & 36 & 2.1 & 3.2 & 0.88 \\
\hline 17 & 0.84 & 1.0 & 2.7 & 1.8 & 128 & 6.3 & 12 & 28 & 26 & 1.9 & 2.2 & 1.0 \\
\hline 18 & 0.73 & 1.0 & 2.4 & 5.6 & 57 & 5.3 & 24 & 24 & 19 & 1.9 & 1.4 & 0.86 \\
\hline 19 & 0.73 & 1.1 & 2.7 & e4.0 & 29 & 5.0 & 43 & 19 & 15 & 2.0 & 1.5 & 10 \\
\hline 20 & 0.76 & 0.92 & 3.3 & $\mathrm{e} 2.5$ & 52 & 5.3 & 87 & 16 & 46 & 1.8 & 12 & 6.3 \\
\hline 21 & 0.65 & 0.92 & 2.1 & e2.0 & 79 & 6.1 & 33 & 14 & 37 & 1.6 & 14 & 2.0 \\
\hline 22 & 0.68 & 4.8 & 1.8 & e2.1 & 34 & 28 & 103 & 12 & 32 & 11 & 6.7 & 0.69 \\
\hline 29 & 2.7 & 2.3 & 1.5 & e1.7 & --- & 5.4 & 26 & 72 & 6.6 & 22 & 1.7 & 7.8 \\
\hline 30 & 2.1 & 31 & 6.0 & e1.6 & --- & 5.0 & 26 & 56 & 5.5 & 13 & 1.2 & 6.2 \\
\hline 31 & 1.4 & --- & 104 & $\mathrm{e} 1.5$ & --- & 4.6 & --- & 37 & --- & 9.1 & 1.0 & --- \\
\hline Total & 78.54 & 119.26 & 251.6 & 149.5 & 588.1 & 601.9 & 856.9 & 1048.4 & 1267.7 & 475.4 & 240.6 & 166.10 \\
\hline Mean & 2.53 & 3.98 & 8.12 & 4.82 & 21.0 & 19.4 & 28.6 & 33.8 & 42.3 & 15.3 & 7.76 & 5.54 \\
\hline $\operatorname{Max}$ & 21 & 31 & 104 & 42 & 128 & 141 & 103 & 192 & 502 & 158 & 35 & 30 \\
\hline Min & 0.20 & 0.74 & 1.2 & 1.5 & 1.1 & 4.6 & 5.1 & 9.4 & 5.5 & 1.6 & 1.0 & 0.22 \\
\hline CFSM & 0.23 & 0.35 & 0.72 & 0.43 & 1.88 & 1.73 & 2.55 & 3.02 & 3.77 & 1.37 & 0.69 & 0.49 \\
\hline In. & 0.26 & 0.40 & 0.84 & 0.50 & 1.95 & 2.00 & 2.85 & 3.48 & 4.21 & 1.58 & 0.80 & 0.55 \\
\hline
\end{tabular}


STATION: 05536500 Tinley Creek near Palos Park, IL

DD \#4

Discharge, cubic feet per second

WATER YEAR OCTOBER 2010 TO SEPTEMBER 2011—Continued

STATISTICS OF MONTHLY MEAN DATA FOR WATER YEARS 1951-2011, BY WATER YEAR YWW)

\begin{tabular}{lcccccccccccc}
\hline & Oct & Nov & Dec & Jan & Feb & Mar & Apr & May & Jun & Jul & Aug & Sep \\
\hline Mean & 6.95 & 9.90 & 10.7 & 11.3 & 13.8 & 21.0 & 21.5 & 15.7 & 12.5 & 6.95 & 6.32 & 6.51 \\
Max & 87.0 & 47.1 & 57.7 & 43.1 & 69.8 & 90.2 & 50.7 & 43.7 & 56.9 & 58.5 & 31.6 & 49.5 \\
$\backslash(\mathrm{WY} \backslash)$ & 1955 & 2004 & 1983 & 1999 & 1997 & 1979 & 1970 & 2002 & 2000 & 1996 & 2007 & 2008 \\
Min & 0.00 & 0.17 & 0.15 & 0.06 & 0.19 & 2.24 & 1.52 & 1.79 & 0.67 & 0.15 & 0.00 & 0.00 \\
$\backslash(\mathrm{W} \backslash)$ & 1953 & 1954 & 1964 & 1977 & 1963 & 1981 & 1963 & 1963 & 1965 & 1956 & 1964 & 1953 \\
\hline
\end{tabular}

SUMMARY STATISTICS

\begin{tabular}{|c|c|c|c|c|c|c|}
\hline & \multicolumn{2}{|c|}{ For 2010 Calendar Year } & \multicolumn{2}{|c|}{ For 2011 Water Year } & \multicolumn{2}{|c|}{ Water Years 1951-2011 } \\
\hline Annual total & 4610.60 & & 5844.00 & & & \\
\hline Annual mean & 12.6 & & 16.0 & & 11.9 & \\
\hline Highest annual mean & & & & & 22.7 & 1993 \\
\hline Lowest annual mean & & & & & 2.27 & 1963 \\
\hline Highest daily mean & 316 & Aug 3 & 502 & Jun 9 & 891 & Oct 101954 \\
\hline Lowest daily mean & 0.18 & Aug 30 & 0.20 & Oct 9 & 0.00 & Sep 291952 \\
\hline Annual seven-day minimum & 0.26 & Aug 26 & 0.28 & Oct 6 & 0.00 & Oct 11952 \\
\hline Maximum peak flow & & & 1500 & Jun 9 & 2010 & Jul 181996 \\
\hline Maximum peak stage & & & 9.53 & Jun 9 & 10.30 & Oct 101954 \\
\hline Instantaneous low flow & & & 0.08 & Sep 23 & & \\
\hline Annual runoff $\backslash(\mathrm{CFSM} \backslash)$ & 1.13 & & 1.43 & & 1.06 & \\
\hline Annual runoff $\backslash$ (inches $\backslash$ ) & 15.31 & & 19.41 & & 14.44 & \\
\hline 10 percent exceeds & 30 & & 35 & & 26 & \\
\hline 50 percent exceeds & 5.0 & & 5.5 & & 3.0 & \\
\hline 90 percent exceeds & 0.73 & & 0.91 & & 0.20 & \\
\hline
\end{tabular}


STATION: 05536500. Tinley Creek near Palos Park, IL

Type:stream, Agency:USGS, State:17, County: 031, Latitude: 413848, Longitude: 0874559 NAD27, Drainage area:11.2, Contributing drainage area:11.20*, Datum: 607.40 NGVD29

Date processed: 2012-01-19 10:31 by adrobl

Lowest aging status in period is APPROVED

DD \#3

Gage height, feet

WATER YEAR OCTOBER 2010 TO SEPTEMBER 2011

DAILY MEAN VALUES

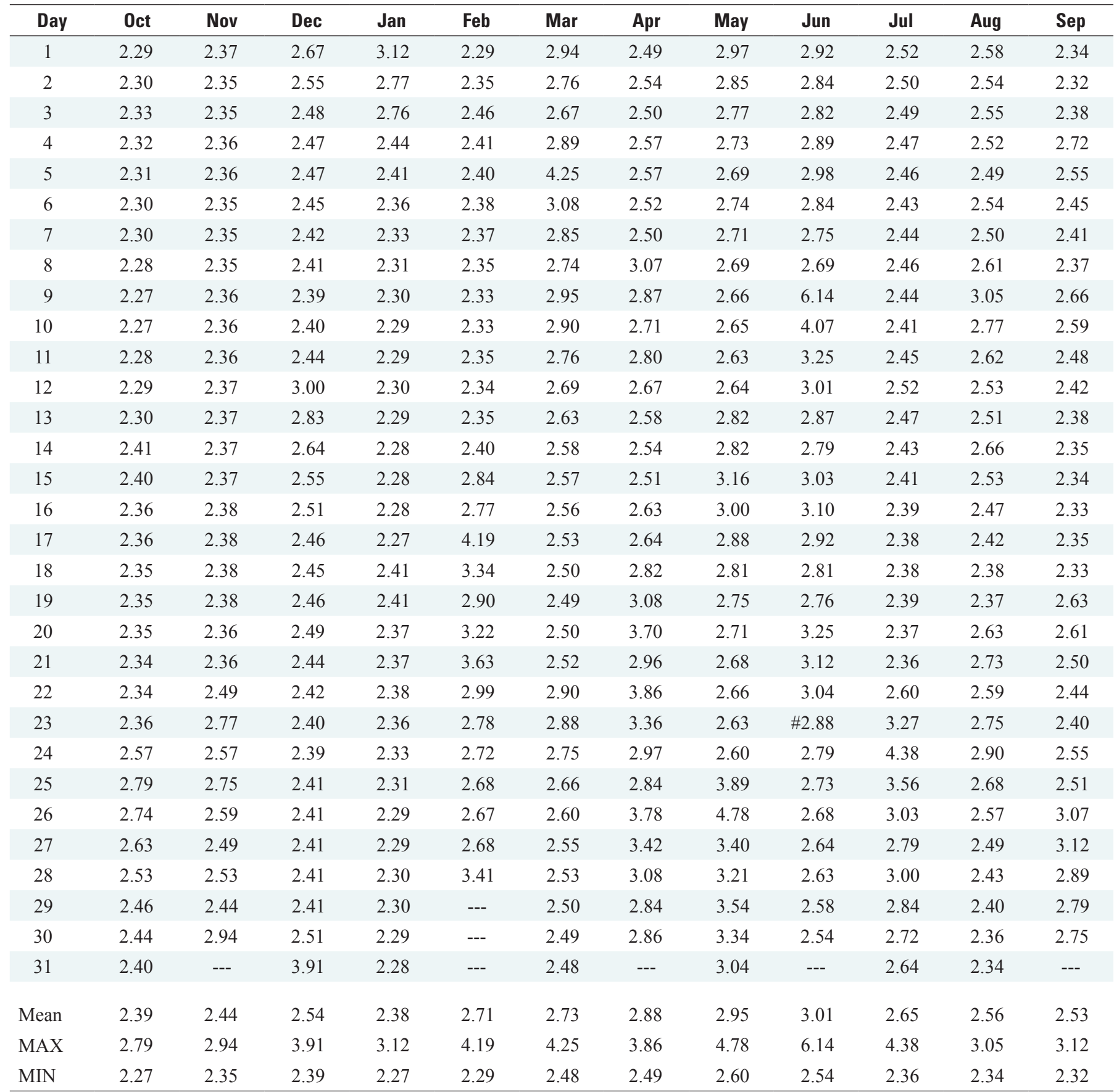


STATION: 05536500 Tinley Creek near Palos Park, IL

Type: stream, Agency: USGS, State: 17, County: 031, Latitude: 413848, Longitude: 0874559 NAD27, Drainage area:11.2,

Contributing drainage area:11.20*, Datum: 607.40 NGVD29

Date processed; 2013-02-07 11:42 by swreview

Lowest aging status in period is APPROVED

DD \#4

Discharge, cubic feet per second

WATER YEAR OCTOBER 2011 TO SEPTEMBER 2012

DAILY MEAN VALUES

\begin{tabular}{|c|c|c|c|c|c|c|c|c|c|c|c|c|}
\hline Day & Oct & Nov & Dec & Jan & Feb & Mar & Apr & May & Jun & Jul & Aug & Sep \\
\hline 1 & 5.3 & 10 & 8.5 & 14 & 22 & 28 & 6.4 & 15 & 24 & 4.8 & 0.51 & 2.7 \\
\hline 2 & 3.2 & 7.1 & 7.8 & 10 & 15 & 22 & 5.8 & 23 & 9.8 & 2.9 & 0.39 & 4.5 \\
\hline 4 & 1.4 & 8.6 & 11 & 6.9 & 26 & 17 & 4.4 & 92 & 3.2 & 0.73 & 9.8 & 1.7 \\
\hline 5 & 0.75 & 7.6 & 9.2 & 6.5 & 25 & 11 & 4.0 & 35 & 2.2 & 0.66 & 24 & 2.5 \\
\hline 7 & 0.25 & 4.9 & 6.0 & 5.8 & 12 & 6.5 & 3.2 & 225 & 1.8 & 0.51 & 2.9 & 1.9 \\
\hline 8 & 0.35 & 52 & 5.6 & 5.2 & 9.7 & 20 & 3.0 & 62 & 1.2 & 0.26 & 1.6 & 2.8 \\
\hline 9 & 0.33 & 60 & 5.1 & 5.0 & 8.3 & 16 & 3.2 & 32 & 0.96 & 0.15 & 1.1 & 3.0 \\
\hline 10 & 0.47 & 32 & 4.3 & 4.6 & 7.5 & 10 & 2.6 & 19 & 0.80 & 0.11 & 0.85 & 1.9 \\
\hline 11 & 0.42 & 21 & 4.3 & 5.0 & 7.5 & 8.3 & 2.4 & 12 & 0.67 & 0.33 & 0.87 & 1.2 \\
\hline 15 & 6.5 & 6.5 & 98 & 4.4 & 6.2 & 9.7 & 3.1 & 11 & 0.61 & 9.2 & 11 & 0.49 \\
\hline 16 & 4.0 & 5.6 & 40 & 4.7 & 26 & 9.3 & 19 & 7.7 & 0.54 & 3.8 & 7.2 & 0.31 \\
\hline 17 & 2.8 & 4.8 & 24 & 22 & 20 & 6.9 & 8.9 & 5.7 & 8.4 & 2.0 & 5.2 & 0.22 \\
\hline 18 & 2.0 & 4.1 & 17 & 27 & 13 & 5.8 & 5.9 & 4.6 & 4.9 & e1.5 & 2.5 & 1.1 \\
\hline 19 & 4.2 & 3.8 & 13 & 13 & 9.2 & 5.4 & 4.4 & 3.8 & 2.5 & e65 & 1.4 & 0.98 \\
\hline 20 & 38 & 3.8 & 10 & e9.0 & 7.8 & 5.2 & 3.8 & 3.3 & 1.4 & 14 & 0.92 & 0.51 \\
\hline 21 & 25 & 3.3 & 9.2 & e8.1 & 8.4 & 5.0 & 3.3 & 5.2 & 1.2 & 4.7 & 2.0 & 0.23 \\
\hline 22 & 14 & 4.6 & 8.2 & e8.3 & 9.2 & 4.6 & 2.9 & 3.9 & 0.75 & 2.4 & 1.1 & 0.25 \\
\hline 29 & 6.5 & 17 & 10 & 18 & 40 & 6.3 & 4.2 & 1.5 & 1.3 & 1.8 & 4.5 & 0.08 \\
\hline 30 & 5.3 & 11 & 17 & 13 & --- & 5.5 & 9.4 & 1.2 & 7.5 & 0.87 & 2.7 & 0.07 \\
\hline 31 & 11 & --- & 20 & 20 & --- & 5.1 & --- & 2.8 & --- & 0.58 & 1.6 & --- \\
\hline Total & 228.30 & 423.5 & 509.6 & 646.9 & 418.9 & 440.2 & 130.8 & 708.3 & 85.66 & 149.70 & 169.45 & 33.79 \\
\hline Mean & 7.36 & 14.1 & 16.4 & 20.9 & 14.4 & 14.2 & 4.36 & 22.8 & 2.86 & 4.83 & 5.47 & 1.13 \\
\hline Max & 38 & 60 & 103 & 225 & 40 & 50 & 19 & 225 & 24 & 65 & 49 & 4.5 \\
\hline Min & 0.25 & 3.3 & 4.1 & 4.4 & 5.8 & 4.6 & 2.2 & 1.2 & 0.32 & 0.11 & 0.19 & 0.07 \\
\hline CFSM & 0.66 & 1.26 & 1.47 & 1.86 & 1.29 & 1.27 & 0.39 & 2.04 & 0.25 & 0.43 & 0.49 & 0.10 \\
\hline In. & 0.76 & 1.41 & 1.69 & 2.15 & 1.39 & 1.46 & 0.43 & 2.35 & 0.28 & 0.50 & 0.56 & 0.11 \\
\hline
\end{tabular}


STATION: 05536500 Tinley Creek near Palos Park, IL

DD \#4

Discharge, cubic feet per second

WATER YEAR OCTOBER 2011 TO SEPTEMBER 2012-Continued

STATISTICS OF MONTHLY MEAN DATA FOR WATER YEARS 1951-2012, BY WATER YEAR (WY)

\begin{tabular}{lccccccccccccc}
\hline & Oct & Nov & Dec & Jan & Feb & Mar & Apr & May & Jun & Jul & Aug & Sep \\
\hline Mean & 6.95 & 9.97 & 10.8 & 11.4 & 13.8 & 20.9 & 21.2 & 15.9 & 12.3 & 6.91 & 6.30 & 6.43 \\
Max & 87.0 & 47.1 & 57.7 & 43.1 & 69.8 & 90.2 & 50.7 & 43.7 & 56.9 & 58.5 & 31.6 & 49.5 \\
(WY) & 1955 & 2004 & 1983 & 1999 & 1997 & 1979 & 1970 & 2002 & 2000 & 1996 & 2007 & 2008 \\
Min & 0.00 & 0.17 & 0.15 & 0.06 & 0.19 & 2.24 & 1.52 & 1.79 & 0.67 & 0.15 & 0.00 & 0.00 \\
(WY $\backslash$ & 1953 & 1954 & 1964 & 1977 & 1963 & 1981 & 1963 & 1963 & 1965 & 1956 & 1964 & 1953 \\
\hline
\end{tabular}

SUMMARY STATISTICS

\begin{tabular}{|c|c|c|c|c|c|c|}
\hline & \multicolumn{2}{|c|}{ For 2011 Calendar Year } & \multicolumn{2}{|c|}{ For 2012 Water Year } & \multicolumn{2}{|c|}{ Water Years 1951-2012 } \\
\hline Annual total & 6556.00 & & 3945.10 & & & \\
\hline Annual mean & 18.0 & & 10.8 & & 11.9 & \\
\hline Highest annual mean & & & & & 22.7 & 1993 \\
\hline Lowest annual mean & & & & & 2.27 & 1963 \\
\hline Highest daily mean & 502 & Jun 9 & 225 & $\operatorname{Jan} 23$ & 891 & Oct 101954 \\
\hline Lowest daily mean & 0.22 & Sep 23 & 0.07 & Sep 30 & 0.00 & Sep 291952 \\
\hline Annual seven-day minimum & 0.39 & Oct 6 & 0.15 & Sep 24 & 0.00 & Oct 11952 \\
\hline Maximum peak flow & & & 446 & May 7 & 2010 & Jul 181996 \\
\hline Maximum peak stage & & & 6.67 & May 7 & 10.30 & Oct 101954 \\
\hline Instantaneous low flow & & & 0.06 & Sep 29 & & \\
\hline Annual runoff $(\mathrm{CFSM} \backslash)$ & 1.60 & & 0.962 & & 1.06 & \\
\hline Annual runoff $\backslash($ inches $\backslash)$ & 21.78 & & 13.10 & & 14.42 & \\
\hline 10 percent exceeds & 38 & & 24 & & 26 & \\
\hline 50 percent exceeds & 8.4 & & 5.2 & & 3.0 & \\
\hline 90 percent exceeds & 1.5 & & 0.51 & & 0.20 & \\
\hline
\end{tabular}


STATION: $05536500 . \quad$ Tinley Creek near Palos Park, IL

Type: stream, Agency: USGS, State: 17, County: 031, Latitude: 413848, Longitude: 0874559 NAD27, Drainage area:11.2,

Contributing drainage area:11.20*, Datum: 607.40 NGVD29

Date processed: 2013-02-07 11:42 by swreview

Lowest aging status in period is APPROVED

\section{DD \#3 \\ Gage height, feet \\ WATER YEAR OCTOBER 2011 TO SEPTEMBER 2012}

DAILY MEAN VALUES

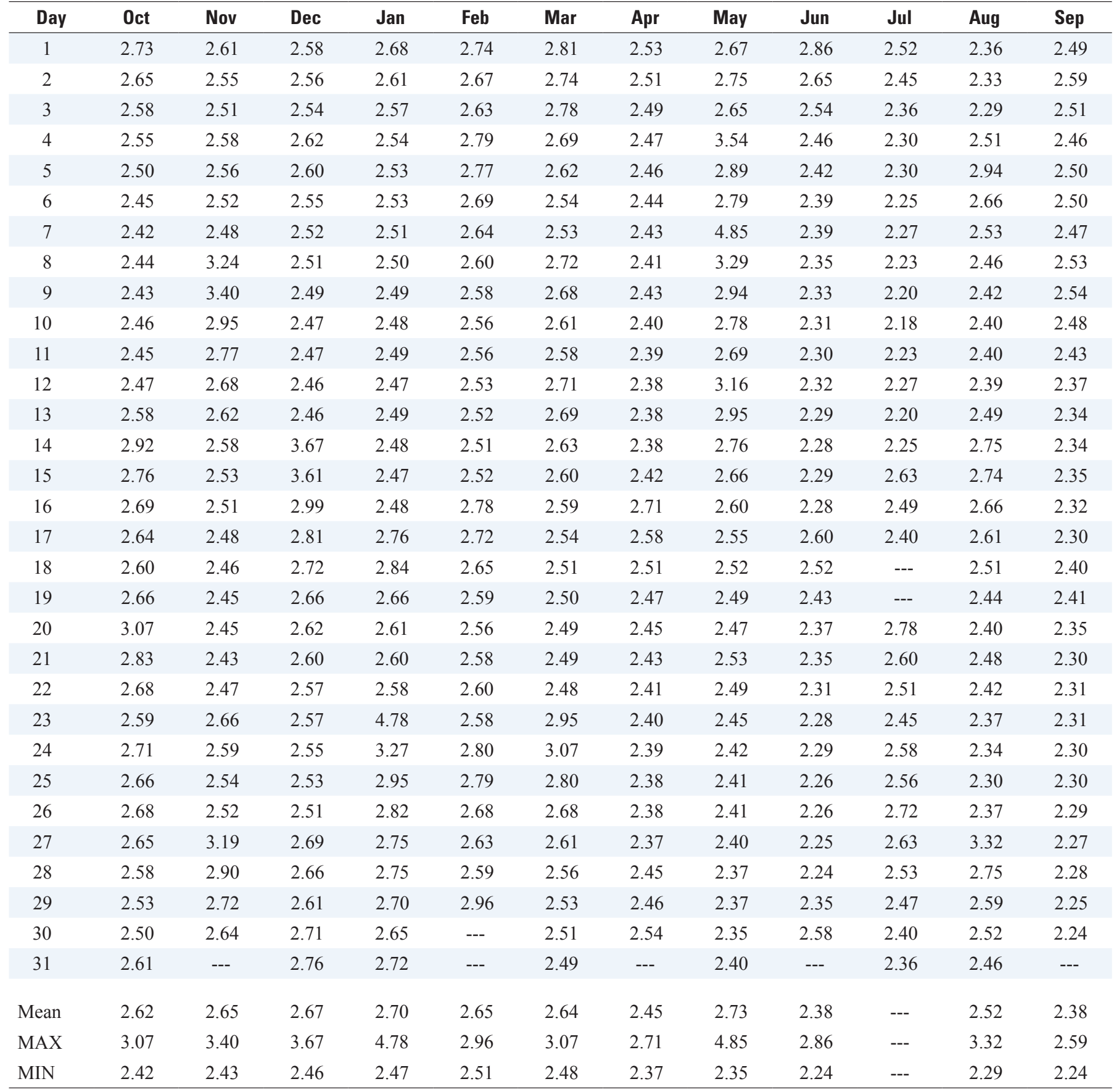


STATION: 05536340 Midlothian Creek at Oak Forest, IL

Type: stream, Agency: USGS, State: 17, County: 031, Latitude: 413651, Longitude: 0874346 NAD27, Drainage area:12.6*,

Contributing drainage area: , Datum: 620.41 NGVD29

Date processed; 2012-01-18 15:32 by adrobl

Lowest aging status in period is APPROVED

DD \#4

Discharge, cubic feet per second

WATER YEAR OCTOBER 2010 TO SEPTEMBER 2011

DAILY MEAN VALUES

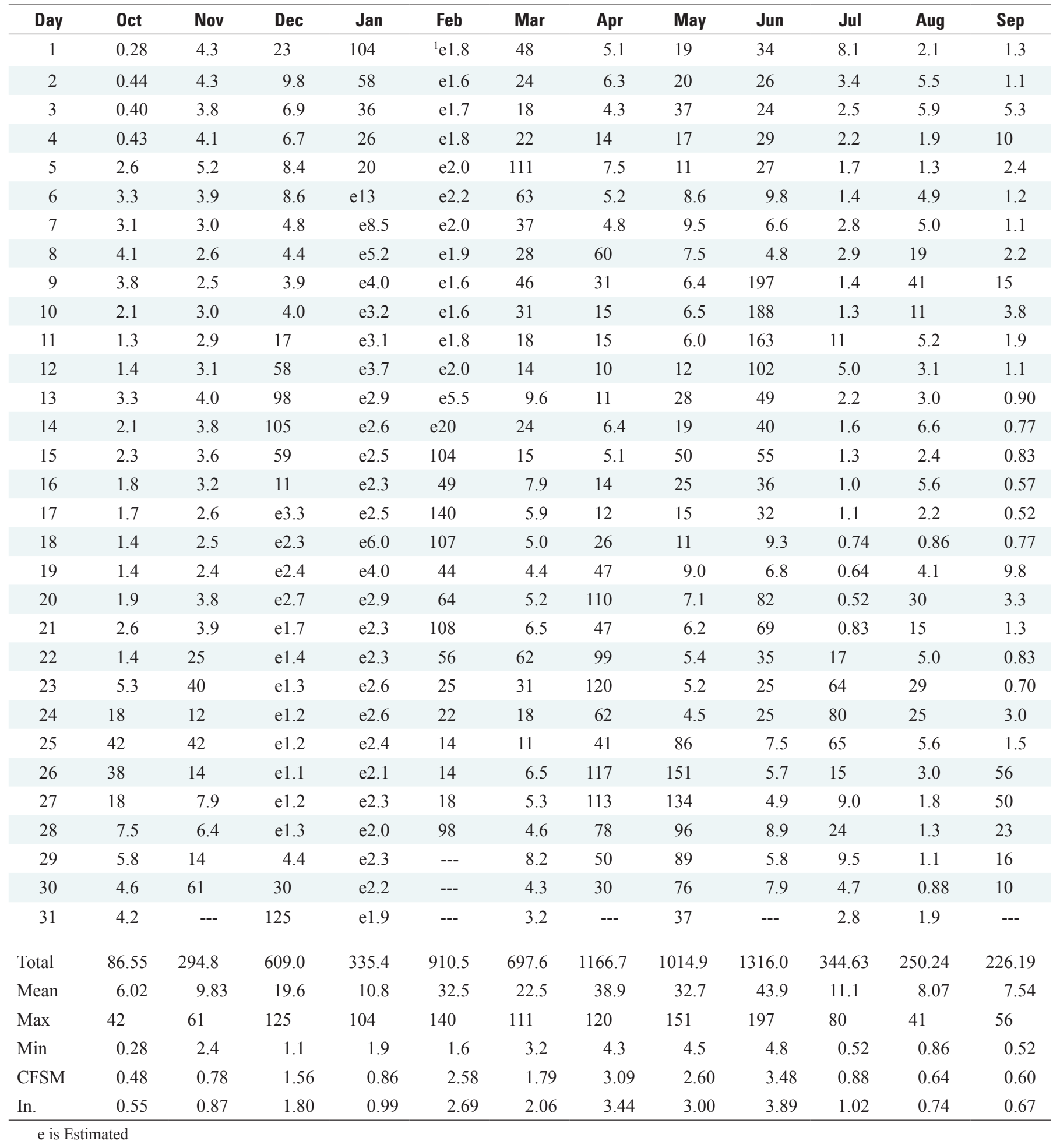


STATION: 05536340 Midlothian Creek at Oak Forest, IL

DD \#4

Discharge, cubic feet per second

WATER YEAR OCTOBER 2010 TO SEPTEMBER 2011—Continued

STATISTICS OF MONTHLY MEAN DATA FOR WATER YEARS 1951-2011, BY WATER YEAR (WW)

\begin{tabular}{lcccccccccccc}
\hline & Oct & Nov & Dec & Jan & Feb & Mar & Apr & May & Jun & Jul & Aug & Sep \\
\hline Mean & 7.88 & 10.4 & 12.1 & 11.2 & 15.0 & 22.4 & 22.3 & 17.0 & 15.1 & 9.33 & 8.17 & 8.86 \\
Max & 70.9 & 40.7 & 70.9 & 43.9 & 64.8 & 86.9 & 53.5 & 46.1 & 61.2 & 57.0 & 47.5 & 85.0 \\
$\backslash(\mathrm{WY} \backslash)$ & 1955 & 1986 & 1983 & 1993 & 1997 & 1979 & 1973 & 1990 & 2000 & 1996 & 2007 & 2008 \\
Min & 0.04 & 0.17 & 0.00 & 0.00 & 0.00 & 3.13 & 1.41 & 1.84 & 0.88 & 0.29 & 0.25 & 0.11 \\
$\backslash(\mathrm{WY} \backslash)$ & 1964 & 1965 & 1963 & 1963 & 1963 & 1964 & 1963 & 1968 & 1965 & 1964 & 1966 & 1963 \\
\hline
\end{tabular}

SUMMARY STATISTICS

\begin{tabular}{|c|c|c|c|c|c|c|}
\hline \multirow[b]{2}{*}{ Annual total } & \multicolumn{2}{|c|}{ For 2010 Calendar Year } & \multicolumn{2}{|c|}{ For 2011 Water Year } & \multicolumn{2}{|c|}{ Water Years 1951-2011 } \\
\hline & 6627.96 & & 7352.51 & & & \\
\hline Annual mean & 18.2 & & 20.1 & & 13.3 & \\
\hline Highest annual mean & & & & & 22.7 & 2008 \\
\hline Lowest annual mean & & & & & 2.68 & 1963 \\
\hline Highest daily mean & 157 & Aug 4 & 197 & Jun 9 & 448 & Oct 111954 \\
\hline Lowest daily mean & 0.24 & Aug 30 & 0.28 & Oct 1 & 0.00 & Oct 301950 \\
\hline Annual seven-day minimum & 0.44 & Sep 28 & 0.78 & Sep 12 & 0.00 & Nov 221962 \\
\hline Maximum peak flow & & & 347 & Jun 9 & 569 & Oct 101954 \\
\hline Maximum peak stage & & & 5.69 & Jun 9 & 9.00 & Jul 131957 \\
\hline Instantaneous low flow & & & 0.160 & Oct 1 & & \\
\hline Annual runoff $(\mathrm{CFSM} \backslash)$ & 1.44 & & 1.60 & & 1.06 & \\
\hline Annual runoff $\backslash($ inches $\backslash)$ & 19.57 & & 21.71 & & 14.34 & \\
\hline 10 percent exceeds & 58 & & 60 & & 35 & \\
\hline 50 percent exceeds & 5.3 & & 5.8 & & 3.9 & \\
\hline 90 percent exceeds & 1.1 & & 1.3 & & 0.60 & \\
\hline
\end{tabular}




\section{STATION: $05536340 . \quad$ Midlothian Creek at Oak Forest, IL}

Type: stream, Agency: USGS, State: 17, County: 031, Latitude: 413651, Longitude: 0874346 NAD27, Drainage area:12.6*,

Contributing drainage area: Datum: 620.41 NGVD29

Date processed: 2012-01-18 15:32 by adrobl

Lowest aging status in period is APPROVED

DD \#3
Gage height, feet
WATER YEAR OCTOBER 2010 TO SEPTEMBER 2011

DAILY MEAN VALUES

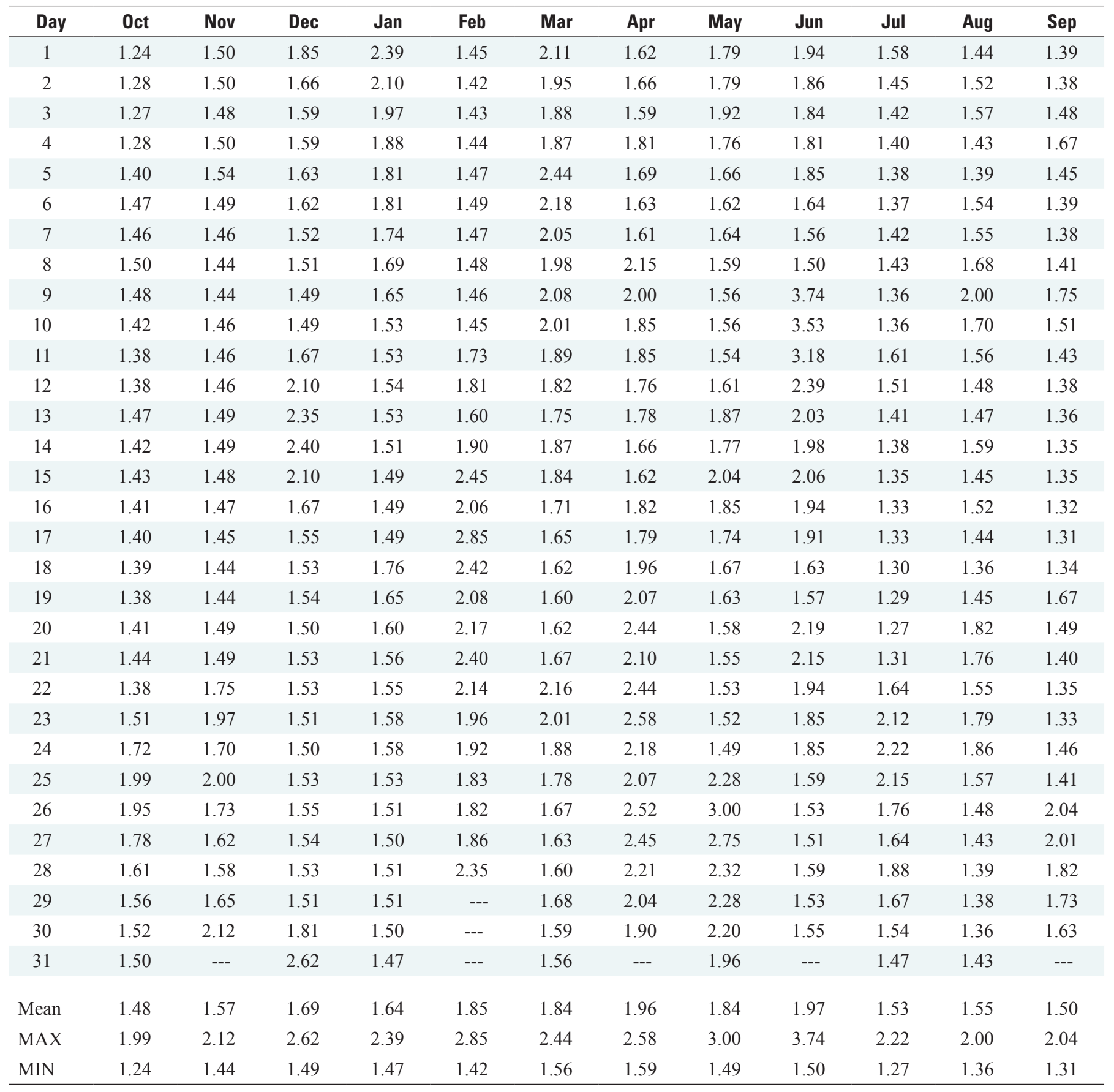




\section{STATION: 05536340 Midlothian Creek at Oak Forest, IL}

Type: stream, Agency: USGS, State: 17, County: 031, Latitude: 413651, Longitude: 0874346 NAD27, Drainage area:12.6*,

Contributing drainage area: Datum: 620.41 NGVD29

Date processed; 2013-02-09 09:07 by swreview

Lowest aging status in period is APPROVED

DD \#4

Discharge, cubic feet per second

WATER YEAR OCTOBER 2011 TO SEPTEMBER 2012

DAILY MEAN VALUES

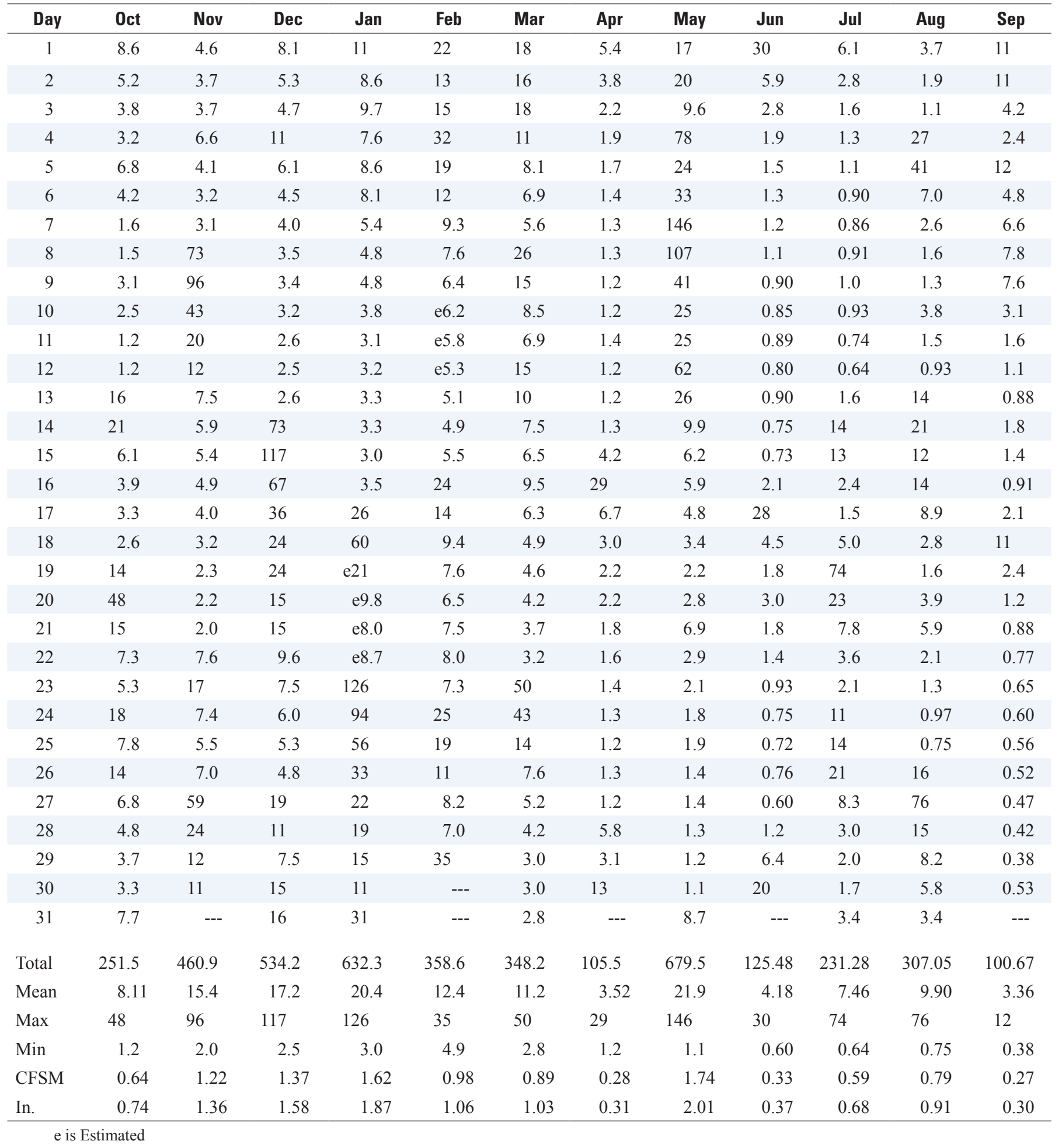


STATION: 05536340 Midlothian Creek at Oak Forest, IL

DD \#4

Discharge, cubic feet per second

WATER YEAR OCTOBER 2011 TO SEPTEMBER 2012—Continued

STATISTICS OF MONTHLY MEAN DATA FOR WATER YEARS 1951-2012, BY WATER YEAR (WY)

\begin{tabular}{lcccccccccccc}
\hline & Oct & Nov & Dec & Jan & Feb & Mar & Apr & May & Jun & Jul & Aug & Sep \\
\hline Mean & 7.88 & 10.5 & 12.2 & 11.4 & 14.9 & 22.2 & 22.0 & 17.1 & 15.0 & 9.30 & 8.19 & 8.77 \\
Max & 70.9 & 40.7 & 70.9 & 43.9 & 64.8 & 86.9 & 53.5 & 46.1 & 61.2 & 57.0 & 47.5 & 85.0 \\
$\backslash($ WY $\backslash)$ & 1955 & 1986 & 1983 & 1993 & 1997 & 1979 & 1973 & 1990 & 2000 & 1996 & 2007 & 2008 \\
Min & 0.04 & 0.17 & 0.00 & 0.00 & 0.00 & 3.13 & 1.41 & 1.84 & 0.88 & 0.29 & 0.25 & 0.11 \\
$\backslash($ WY $\backslash)$ & 1964 & 1965 & 1963 & 1963 & 1963 & 1964 & 1963 & 1968 & 1965 & 1964 & 1966 & 1963 \\
\hline
\end{tabular}

SUMMARY STATISTICS

\begin{tabular}{|c|c|c|c|c|c|c|}
\hline & \multicolumn{2}{|c|}{ For 2011 Calendar Year } & \multicolumn{2}{|c|}{ For 2012 Water Year } & \multicolumn{2}{|c|}{ Water Years 1951-2012 } \\
\hline Annual total & 7508.76 & & 4135.18 & & & \\
\hline Annual mean & 20.6 & & 11.3 & & 13.3 & \\
\hline Highest annual mean & & & & & 22.7 & 2008 \\
\hline Lowest annual mean & & & & & 2.68 & 1963 \\
\hline Highest daily mean & 197 & Jun 9 & 146 & May 7 & 448 & Oct 111954 \\
\hline Lowest daily mean & 0.52 & Jul 20 & 0.38 & Sep 29 & 0.00 & Oct 301950 \\
\hline Annual seven-day minimum & 0.78 & Sep 12 & 0.50 & Sep 24 & 0.00 & Nov 221962 \\
\hline Maximum peak flow & & & 207 & Jan 23 & 569 & Oct 101954 \\
\hline Maximum peak stage & & & 3.81 & Jan 23 & 9.00 & Jul 131957 \\
\hline Instantaneous low flow & & & 0.08 & Aug 3 & & \\
\hline Annual runoff (CFSM) & 1.63 & & 0.897 & & 1.05 & \\
\hline Annual runoff (inches) & 22.17 & & 12.21 & & 14.30 & \\
\hline 10 percent exceeds & 62 & & 25 & & 34 & \\
\hline 50 percent exceeds & 6.8 & & 5.2 & & 3.9 & \\
\hline 90 percent exceeds & 1.6 & & 1.1 & & 0.60 & \\
\hline
\end{tabular}


STATION: $05536340 . \quad$ Midlothian Creek at Oak Forest IL

Type: stream, Agency: USGS, State: 17, County: 031, Latitude: 413651, Longitude: 0874346 NAD27, Drainage area:12.6*, Contributing drainage area: Datum: 620.41 NGVD29 Date processed: 2013-02-09 09:07 by swreview

Lowest aging status in period is APPROVED

DD \#3

Gage height, feet

WATER YEAR OCTOBER 2011 TO SEPTEMBER 2012

DAILY MEAN VALUES

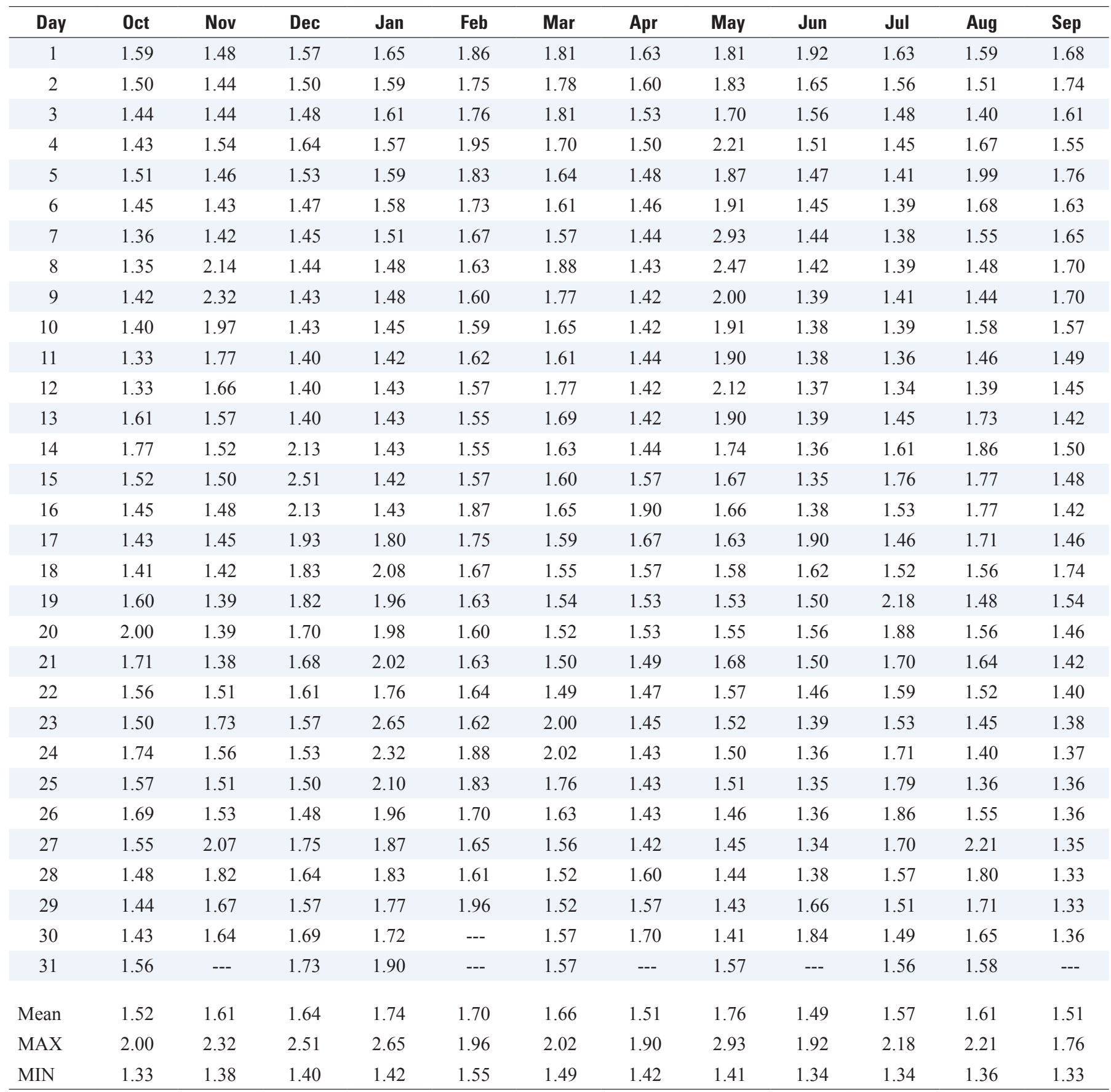


STATION: 05533400 Sawmill Creek near Lemont, IL

Type: stream, Agency: USGS, State: 17, County: 043, Latitude: 414228, Longitude: 0875746 NAD83, Drainage area:13.0,

Contributing drainage area:13.00*, Datum: 630.00 NGVD29

Date processed; 2012-10-12 13:37 by mjlee

Lowest aging status in period is WORKING

DD \#5

Discharge, cubic feet per second

WATER YEAR OCTOBER 2010 TO SEPTEMBER 2011

DAILY MEAN VALUES

\begin{tabular}{|c|c|c|c|c|c|c|c|c|c|c|c|c|}
\hline Day & Oct & Nov & Dec & Jan & Feb & Mar & Apr & May & Jun & Jul & Aug & Sep \\
\hline 1 & 0.11 & 0.41 & 5.3 & 77 & 1.1 & 19 & 3.1 & 6.9 & 12 & 1.8 & 4.1 & 0.71 \\
\hline 2 & 0.20 & 0.38 & 2.9 & 36 & 1.3 & 10 & 2.8 & 5.3 & 6.3 & 1.6 & 4.4 & 0.61 \\
\hline 4 & 0.30 & 0.58 & 2.3 & 7.1 & 1.6 & 25 & 3.6 & 3.2 & 3.8 & 1.2 & 2.8 & 3.5 \\
\hline 5 & 0.19 & $\# 0.41$ & $\# 2.7$ & 5.7 & 1.6 & 108 & 2.3 & 3.3 & 2.8 & 1.0 & 1.9 & 1.2 \\
\hline 7 & 0.10 & $\mathrm{e} 0.31$ & e1.6 & 3.2 & 1.3 & 16 & 2.2 & 2.9 & 1.6 & 1.7 & 17 & 0.70 \\
\hline 8 & 0.06 & $\# 0.20$ & e1.3 & 2.6 & 1.2 & 9.3 & 58 & 2.3 & 1.3 & 1.0 & 11 & 0.56 \\
\hline 9 & 0.04 & 0.50 & $\mathrm{e} 1.2$ & 2.1 & 1.3 & 44 & 16 & 2.0 & 481 & 0.81 & 9.0 & 0.66 \\
\hline 10 & 0.04 & 0.30 & 1.2 & 2.0 & $\# 1.7$ & 21 & 8.8 & 1.8 & 96 & 0.72 & 3.0 & 0.68 \\
\hline 11 & 0.02 & 0.19 & 21 & 1.8 & 1.5 & 11 & 7.3 & 2.1 & 46 & 5.1 & 1.8 & 0.56 \\
\hline 15 & 0.40 & 0.11 & 2.1 & 1.4 & 21 & 3.7 & 2.7 & 4.6 & 56 & 0.71 & 1.8 & 0.46 \\
\hline 16 & 0.38 & 0.14 & 2.3 & 1.3 & 32 & 3.0 & 8.1 & 2.2 & 34 & 0.54 & 1.2 & 0.41 \\
\hline 17 & 0.28 & 0.26 & 1.5 & 1.3 & 163 & 2.6 & 4.5 & 1.5 & 15 & 0.34 & 1.4 & 0.39 \\
\hline 18 & 0.28 & 0.18 & 1.4 & 9.6 & 82 & 2.3 & 27 & 1.2 & 7.3 & 0.29 & 0.91 & 0.86 \\
\hline 19 & 0.32 & $\mathrm{e} 0.17$ & 1.2 & 3.4 & 29 & 1.9 & 65 & 1.1 & 5.2 & 0.42 & 0.77 & 11 \\
\hline 20 & 0.16 & $\mathrm{e} 0.15$ & 2.0 & 2.0 & 93 & 4.6 & 87 & 1.0 & 59 & 0.28 & 6.6 & 1.6 \\
\hline 21 & 0.05 & $\mathrm{e} 0.12$ & 1.4 & 1.9 & 103 & 7.5 & 25 & 0.95 & 58 & 0.32 & 2.6 & 0.95 \\
\hline 22 & 0.00 & e4.1 & 1.3 & 2.8 & 28 & 29 & 114 & 0.87 & 58 & 22 & 1.3 & 0.64 \\
\hline 29 & 0.72 & 6.1 & 1.1 & 1.2 & --- & 2.1 & 20 & 138 & 2.6 & 28 & 0.79 & 14 \\
\hline 30 & 0.56 & 24 & 24 & 1.2 & --- & 1.9 & 12 & 65 & 2.3 & 11 & 0.76 & 5.3 \\
\hline 31 & 0.47 & --- & 196 & 1.1 & --- & 1.7 & --- & 21 & --- & 6.5 & 0.95 & --- \\
\hline Total & 22.67 & 80.94 & 328.4 & 201.9 & 702.3 & 424.6 & 849.9 & 660.53 & 1057.5 & 640.45 & 154.95 & 165.05 \\
\hline Mean & 0.73 & 2.70 & 10.6 & 6.51 & 25.1 & 13.7 & 28.3 & 21.3 & 35.2 & 20.7 & 5.00 & 5.50 \\
\hline Max & 6.6 & 24 & 196 & 77 & 163 & 108 & 116 & 185 & 481 & 253 & 36 & 45 \\
\hline Min & 0.00 & 0.11 & 1.1 & 1.1 & 1.1 & 1.7 & 1.6 & 0.73 & 1.3 & 0.28 & 0.76 & 0.39 \\
\hline CFSM & 0.06 & 0.21 & 0.81 & 0.50 & 1.93 & 1.05 & 2.18 & 1.64 & 2.71 & 1.59 & 0.38 & 0.42 \\
\hline In. & 0.06 & 0.23 & 0.94 & 0.58 & 2.01 & 1.22 & 2.43 & 1.89 & 3.03 & 1.83 & 0.44 & 0.47 \\
\hline
\end{tabular}


STATION: 05533400 Sawmill Creek near Lemont, IL

DD \#4

Discharge, cubic feet per second

WATER YEAR OCTOBER 2010 TO SEPTEMBER 2011—Continued

STATISTICS OF MONTHLY MEAN DATA FOR WATER YEARS 1986-2011, BY WATER YEAR (WY)

\begin{tabular}{lccccccccccccc}
\hline & Oct & Nov & Dec & Jan & Feb & Mar & Apr & May & Jun & Jul & Aug & Sep \\
\hline Mean & 7.06 & 10.1 & 11.0 & 11.0 & 14.7 & 17.3 & 18.1 & 16.5 & 13.1 & 9.76 & 9.59 & 8.15 \\
Max & 27.2 & 37.4 & 49.3 & 30.6 & 54.5 & 56.3 & 53.4 & 49.3 & 57.6 & 58.6 & 29.9 & 55.6 \\
(WY) & 2010 & 1991 & 2009 & 1993 & 1997 & 2009 & 1999 & 1990 & 1993 & 1996 & 2007 & 2008 \\
Min & 0.19 & 0.68 & 0.22 & 0.17 & 0.16 & 3.54 & 4.88 & 1.25 & 0.77 & 0.14 & 0.31 & 0.10 \\
(WY) & 2006 & 2003 & 2003 & 2003 & 2003 & 2000 & 2004 & 1992 & 2005 & 1991 & 2005 & 1995 \\
\hline
\end{tabular}

SUMMARY STATISTICS

\begin{tabular}{lcccccr}
\hline & For 2010 Calendar Year & For 2011 Water Year & \multicolumn{2}{c}{ Water Years 1986-2011 } \\
\hline Annual total & 4930.47 & 5289.19 & & & \\
Annual mean & 13.5 & & 14.5 & & 2.1 & \\
Highest annual mean & & & & & 20.2 & 2009 \\
Lowest annual mean & & & & & 5.39 & 2003 \\
Highest daily mean & 440 & Jul 24 & 481 & Jun 9 & 1220 & Jul 18 1996 \\
Lowest daily mean & 0.00 & Oct 22 & 0.00 & Oct 22 & 0.00 & Oct 9 1988 \\
Annual seven-day minimum & 0.06 & Oct 6 & 0.06 & Oct 6 & 0.00 & Jul 24 1991 \\
Maximum peak flow & & & 1040 & Jun 9 & 3070 & Jul 18 1996 \\
Maximum peak stage & & & 13.67 & Jun 9 & 17.53 & Jul 18 1996 \\
Instantaneous low flow & & & 0.00 & Oct 11 & & \\
Annual runoff (CFSM) & 1.04 & & 1.11 & & 0.930 & \\
Annual runoff (inches) & 14.11 & & 15.14 & & 12.63 & \\
10 percent exceeds & 32 & 35 & & 35 & \\
50 percent exceeds & 2.7 & 2.2 & & 3.4 & \\
90 percent exceeds & 0.31 & 0.34 & & 0.60 & \\
\hline
\end{tabular}


STATION: 05533400 Sawmill Creek near Lemont, IL

Type: stream, Agency: USGS, State: 17, County: 043, Latitude: 414228, Longitude: 0875746 NAD83, Drainage area:13.0, Contributing drainage area:13.00 *, Datum: 630.00 NGVD29

Date processed; 2012-10-12 13:37 by mjlee

Lowest aging status in period is WORKING

DD \#4

Gage height, feet

WATER YEAR OCTOBER 2010 TO SEPTEMBER 2011

DAILY MEAN VALUES

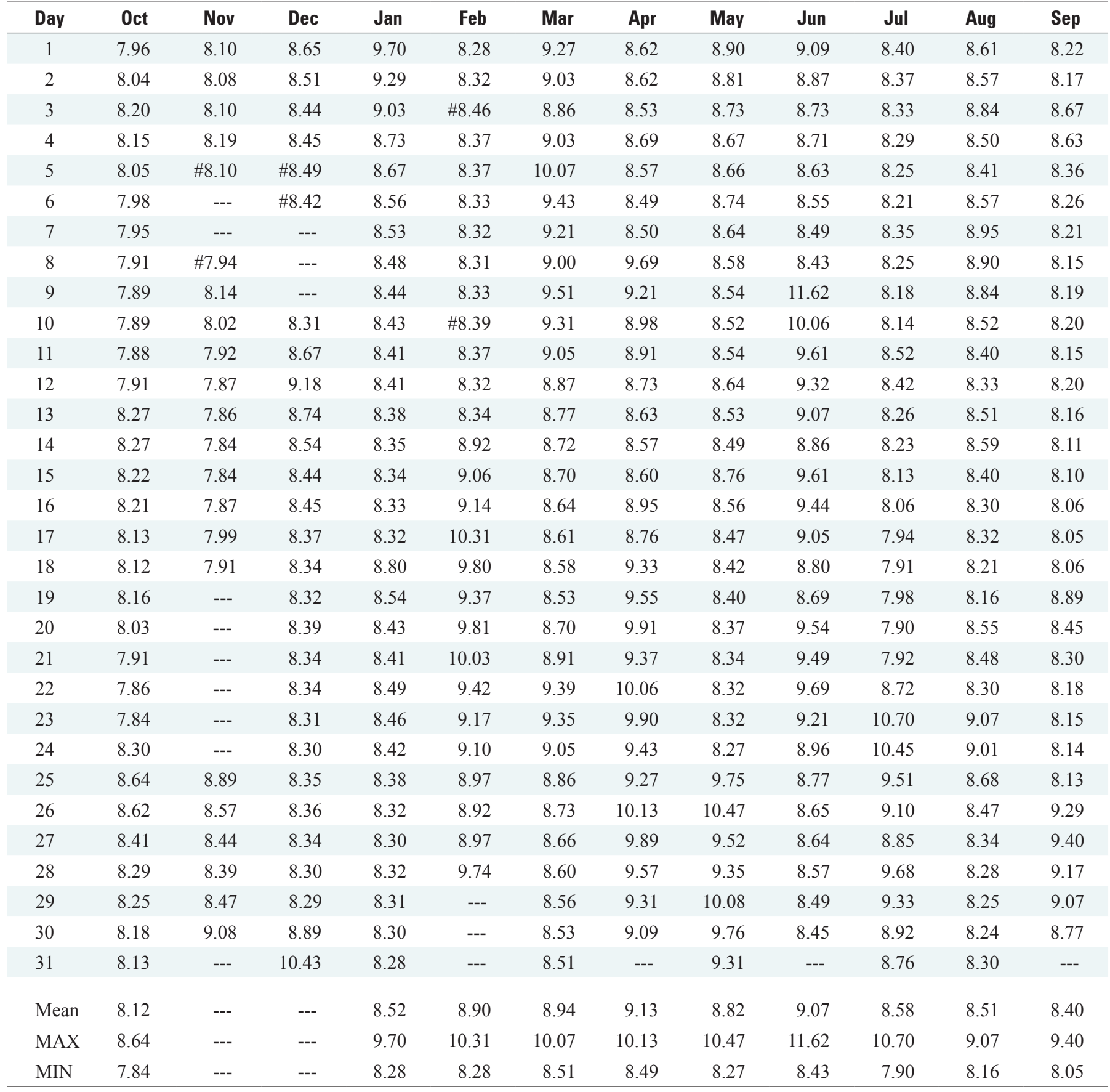

\# Value is write-protected with a " 1 " 
STATION: 05533400 Sawmill Creek near Lemont, IL

Type: stream, Agency: USGS, State: 17, County: 043, Latitude: 414228, Longitude: 0875746 NAD83, Drainage area:13.0, Contributing drainage area:13.00 *, Datum: 630.00 NGVD29

Date processed; 2013-01-25 09:16 by johnsonk

Lowest aging status in period is APPROVED

DD \#5

Discharge, cubic feet per second

WATER YEAR OCTOBER 2011 TO SEPTEMBER 2012

DAILY MEAN VALUES

\begin{tabular}{|c|c|c|c|c|c|c|c|c|c|c|c|c|}
\hline Day & Oct & Nov & Dec & Jan & Feb & Mar & Apr & May & Jun & Jul & Aug & Sep \\
\hline 1 & 3.0 & 1.8 & 6.1 & 8.4 & 12 & 12 & 6.3 & 21 & 6.3 & 0.25 & 0.34 & 3.0 \\
\hline 2 & 2.2 & 1.7 & 4.8 & 6.0 & 8.1 & 16 & 4.5 & 18 & 1.5 & 0.25 & 0.14 & 2.0 \\
\hline 4 & 1.5 & 3.0 & 16 & 4.3 & 8.3 & 9.1 & 2.9 & 70 & 0.71 & 0.01 & 21 & 0.91 \\
\hline 5 & 1.2 & 2.6 & 7.1 & 4.0 & 6.8 & 6.9 & 2.6 & 16 & 0.56 & 0.00 & 7.1 & 2.4 \\
\hline 7 & 2.0 & 1.4 & 4.7 & 3.8 & 5.2 & 5.6 & 2.1 & 187 & 0.25 & 0.00 & 0.93 & 2.6 \\
\hline 8 & 1.2 & 103 & 4.1 & 3.3 & 4.6 & 10 & 2.0 & 46 & 0.21 & 0.00 & 0.55 & 1.4 \\
\hline 9 & 0.68 & 101 & 3.9 & 3.2 & 4.3 & 5.9 & 1.8 & 18 & 0.18 & $\# 0.00$ & 0.28 & 2.8 \\
\hline 10 & 0.63 & 33 & 3.3 & 3.0 & 4.3 & 4.7 & 1.7 & 8.5 & 0.15 & $\# 0.00$ & 0.69 & 1.1 \\
\hline 11 & 0.87 & 15 & 3.0 & 3.1 & 4.2 & 4.4 & 2.2 & 4.4 & 0.17 & $\# 0.00$ & 0.35 & 0.86 \\
\hline 15 & 1.7 & 4.5 & 73 & 2.7 & 3.7 & 4.7 & 84 & 2.4 & 0.09 & 0.94 & 0.50 & 0.70 \\
\hline 16 & 1.2 & 3.8 & 28 & 3.4 & 12 & 4.3 & 55 & 2.2 & 0.01 & 0.18 & 2.5 & 0.43 \\
\hline 17 & 1.3 & 3.2 & 15 & 20 & 6.1 & 3.9 & 16 & 1.5 & 4.8 & 0.07 & 1.3 & 0.35 \\
\hline 18 & 0.90 & 2.8 & 9.6 & 12 & 5.0 & 3.7 & 8.7 & 1.2 & 0.77 & 2.9 & 0.83 & 2.4 \\
\hline 19 & 9.2 & 2.6 & 8.5 & 7.4 & 4.3 & 3.5 & 6.6 & 1.1 & 0.22 & 30 & 0.43 & 0.86 \\
\hline 20 & 20 & 2.4 & 6.9 & 6.1 & 4.0 & 3.3 & 5.3 & 1.0 & 0.17 & 3.1 & 0.73 & 0.62 \\
\hline 21 & 4.2 & 2.1 & 5.4 & 5.3 & 5.0 & 3.0 & 4.4 & 2.9 & 0.16 & 1.5 & 1.3 & 0.42 \\
\hline 22 & 2.5 & 4.1 & 4.8 & 5.0 & 4.8 & 3.4 & 3.8 & 1.5 & 0.05 & 0.72 & 0.67 & 0.41 \\
\hline 29 & 2.1 & 12 & 4.0 & 8.7 & 32 & 3.4 & 3.2 & 0.34 & 0.00 & 0.24 & 3.4 & 0.08 \\
\hline 30 & 1.9 & 8.1 & 23 & 7.4 & --- & 10 & 11 & 0.25 & 0.94 & 0.13 & 2.1 & 0.06 \\
\hline 31 & 2.1 & --- & 16 & 12 & --- & 5.3 & --- & 6.7 & --- & 0.88 & 1.3 & --- \\
\hline Total & 101.08 & 495.2 & 410.0 & 396.7 & 207.8 & 230.4 & 253.3 & 471.91 & 19.18 & 52.94 & 162.07 & 29.65 \\
\hline Mean & 3.26 & 16.5 & 13.2 & 12.8 & 7.17 & 7.43 & 8.44 & 15.2 & 0.64 & 1.71 & 5.23 & 0.99 \\
\hline Max & 20 & 103 & 116 & 143 & 32 & 30 & 84 & 187 & 6.3 & 30 & 56 & 3.0 \\
\hline Min & 0.63 & 1.4 & 3.0 & 2.7 & 3.6 & 3.0 & 1.6 & 0.25 & 0.00 & 0.00 & 0.07 & 0.06 \\
\hline CFSM & 0.25 & 1.27 & 1.02 & 0.98 & 0.55 & 0.57 & 0.65 & 1.17 & 0.05 & 0.13 & 0.40 & 0.08 \\
\hline In. & 0.29 & 1.42 & 1.17 & 1.14 & 0.59 & 0.66 & 0.72 & 1.35 & 0.05 & 0.15 & 0.46 & 0.08 \\
\hline
\end{tabular}


STATION: 05533400 Sawmill Creek near Lemont, IL

DD \#4

Discharge, cubic feet per second

WATER YEAR OCTOBER 2011 TO SEPTEMBER 2012-Continued

STATISTICS OF MONTHLY MEAN DATA FOR WATER YEARS 1986-2012, BY WATER YEAR (WY)

\begin{tabular}{lcccccccccccc}
\hline & Oct & Nov & Dec & Jan & Feb & Mar & Apr & May & Jun & Jul & Aug & Sep \\
\hline Mean & 6.91 & 10.4 & 11.1 & 11.1 & 14.4 & 16.9 & 17.7 & 16.4 & 12.7 & 9.46 & 9.42 & 7.89 \\
Max & 27.2 & 37.4 & 49.3 & 30.6 & 54.5 & 56.3 & 53.4 & 49.3 & 57.6 & 58.6 & 29.9 & 55.6 \\
(WY) & 2010 & 1991 & 2009 & 1993 & 1997 & 2009 & 1999 & 1990 & 1993 & 1996 & 2007 & 2008 \\
Min & 0.19 & 0.68 & 0.22 & 0.17 & 0.16 & 3.54 & 4.88 & 1.25 & 0.64 & 0.14 & 0.31 & 0.10 \\
(WY) & 2006 & 2003 & 2003 & 2003 & 2003 & 2000 & 2004 & 1992 & 2012 & 1991 & 2005 & 1995 \\
\hline
\end{tabular}

SUMMARY STATISTICS

\begin{tabular}{|c|c|c|c|c|c|c|}
\hline & \multicolumn{2}{|c|}{ For 2011 Calendar Year } & \multicolumn{2}{|c|}{ For 2012 Water Year } & \multicolumn{2}{|c|}{ Water Years 1986-2012 } \\
\hline Annual total & 5863.46 & & 2830.23 & & & \\
\hline Annual mean & 16.1 & & 7.73 & & 11.9 & \\
\hline Highest annual mean & & & & & 20.2 & 2009 \\
\hline Lowest annual mean & & & & & 5.39 & 2003 \\
\hline Highest daily mean & 481 & Jun 9 & 187 & May 7 & 1220 & Jul 181996 \\
\hline Lowest daily mean & 0.28 & Jul 20 & 0.00 & Jun 23 & 0.00 & Oct 91988 \\
\hline Annual seven-day minimum & 0.41 & Jul 15 & 0.00 & Jun 23 & 0.00 & Jul 241991 \\
\hline Maximum peak flow & & & 375 & May 7 & 3070 & Jul 181996 \\
\hline Maximum peak stage & & & 11.38 & May 7 & 17.53 & Jul 181996 \\
\hline Instantaneous low flow & & & 0.00 & Jun 13 & & \\
\hline Annual runoff (CFSM) & 1.24 & & 0.595 & & 0.917 & \\
\hline Annual runoff (inches) & 16.78 & & 8.10 & & 12.46 & \\
\hline 10 percent exceeds & 40 & & 16 & & 26 & \\
\hline 50 percent exceeds & 3.5 & & 3.1 & & 3.3 & \\
\hline 90 percent exceeds & 0.87 & & 0.17 & & 0.29 & \\
\hline
\end{tabular}


STATION: 05533400 Sawmill Creek near Lemont, IL

Type: stream, Agency: USGS, State: 17, County: 043, Latitude: 414228, Longitude: 0875746 NAD83, Drainage area:13.0, Contributing drainage area:13.00 *, Datum: 630.00 NGVD29

Date processed; 2012-10-12 13:37 by mjlee

Lowest aging status in period is WORKING

DD \#4

Gage height, feet

WATER YEAR OCTOBER 2010 TO SEPTEMBER 2011

DAILY MEAN VALUES

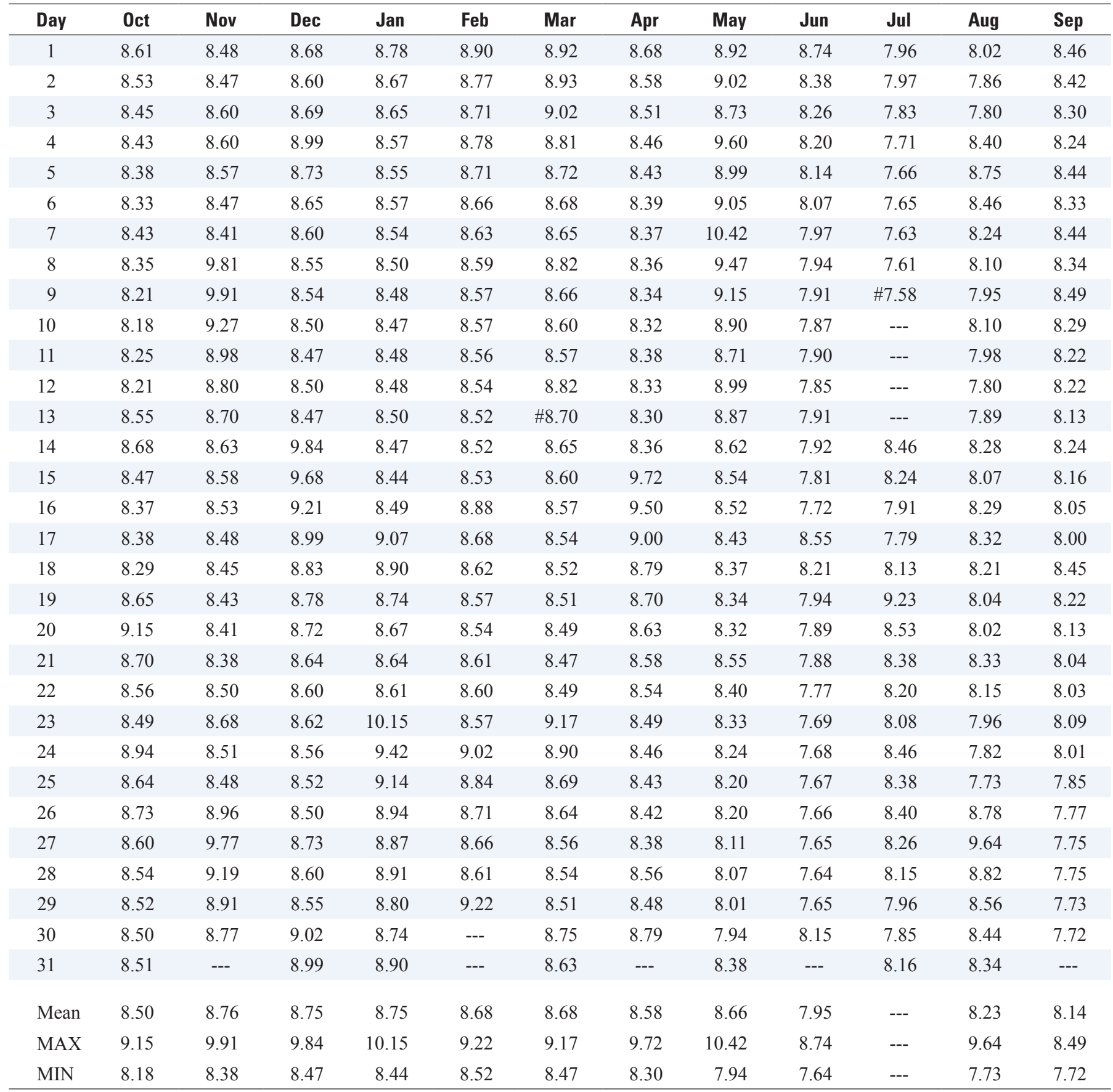

\# Value is write-protected with a "1" 


